\title{
Comparison of Impact Toughness in Simulated Coarse-Grained Heat-Affected Zone of Al-Deoxidized and Ti-Deoxidized Offshore Steels
}

\author{
Henri Tervo ${ }^{1, *(D)}$, Antti Kaijalainen ${ }^{1}\left(\mathbb{D}\right.$, Vahid Javaheri ${ }^{1} \mathbb{D}$, Mohammed Ali ${ }^{1,2}\left(\mathbb{D}\right.$, Tuomas $^{\text {Alatarvas }}{ }^{3}(\mathbb{D}$, \\ Mikko Mehtonen ${ }^{4}$, Severi Anttila ${ }^{4}$ and Jukka Kömi ${ }^{1}$
}

1 Materials and Mechanical Engineering, Centre for Advanced Steel Research, University of Oulu, P.O. Box 4200, FI-90014 Oulu, Finland; antti.kaijalainen@oulu.fi (A.K.); vahid.javaheri@oulu.fi (V.J.); mohammed.ali@oulu.fi (M.A.); jukka.komi@oulu.fi (J.K.)

2 Steel Technology Department, Central Metallurgical Research and Development Institute, Helwan 11421, Egypt

3 Process Metallurgy Research Unit, Centre for Advanced Steel Research, University of Oulu, P.O. Box 4300, FI-90014 Oulu, Finland; tuomas.alatarvas@oulu.fi

4 SSAB Europe, Rautaruukintie 155, P.O. Box 93, FI-92101 Raahe, Finland; mikko.mehtonen@ssab.com (M.M.); severi.anttila@ssab.com (S.A.)

* Correspondence: henri.tervo@oulu.fi

check for updates

Citation: Tervo, H.; Kaijalainen, A.; Javaheri, V.; Ali, M.; Alatarvas, T.; Mehtonen, M.; Anttila, S.; Kömi, J. Comparison of Impact Toughness in Simulated Coarse-Grained Heat-Affected Zone of Al-Deoxidized and Ti-Deoxidized Offshore Steels. Metals 2021, 11, 1783. https:// doi.org/10.3390/met11111783

Academic Editor: Koh-ichi Sugimoto

Received: 7 October 2021

Accepted: 2 November 2021

Published: 5 November 2021

Publisher's Note: MDPI stays neutral with regard to jurisdictional claims in published maps and institutional affiliations.

Copyright: (c) 2021 by the authors. Licensee MDPI, Basel, Switzerland. This article is an open access article distributed under the terms and conditions of the Creative Commons Attribution (CC BY) license (https:// creativecommons.org/licenses/by/ $4.0 /)$.
Abstract: The presence of acicular ferrite (AF) in the heat-affected zone (HAZ) of steels used offshore is generally seen as beneficial for toughness. In this study, the effects of varying fractions of AF (0-49 vol.\%) were assessed in the simulated, unaltered and coarse-grained heat-affected zones (CGHAZ) of three experimental steels. Two steels were deoxidized using Ti and one using Al. The characterization was carried out by using electron microscopy, energy-dispersive X-ray spectrometry, electron backscatter diffraction and X-ray diffraction. The fraction of AF varied with the heat input and cooling time applied in the Gleeble thermomechanical simulator. AF was present in one of the Ti-deoxidized steels with all the applied cooling times, and its fraction increased with increasing cooling time. However, in other materials, only a small fraction (13-22\%) of AF was present and only when the longest cooling time was applied. The impact toughness of the simulated specimens was evaluated using instrumented Charpy V-notch testing. Contrary to the assumption, the highest impact toughness was obtained in the conventional Al-deoxidized steel with little or no AF in the microstructure, while the variants with the highest fraction of AF had the lowest impact toughness. It was concluded that the coarser microstructural and inclusion features of the steels with AF and also the fraction of AF may not have been great enough to improve the CGHAZ toughness of the steels investigated.

Keywords: CGHAZ; acicular ferrite; Ti-deoxidized steel; inclusions; precipitates; instrumented CVN; impact toughness

\section{Introduction}

The demand for steels that can withstand harsh environmental conditions is increasing due to the opening of new oil fields in ever colder climates. The fine-grained microstructure of the steels used offshore is typically provided by thermomechanically controlled hot rolling processes (TMCP). Both high strength and high toughness in the base plate are obtained by utilizing this approach. Furthermore, weldability is enhanced by using moderately low amounts of carbon and other alloying elements. The combination of strength, toughness and weldability provided by TMCP in these steels is also beneficial for other structural uses [1].

Standards such as, for example, EN 10225-1 require offshore steels to be weldable using submerged arc welding (SAW), gas-metal arc welding (GMAW) or flux-cored arc 
welding (FCAW) processes [2]. The degradation of material properties, such as toughness in the weld heat-affected zone (HAZ), is required to remain tolerable. Especially in the most typically vulnerable zones, such as the coarse-grained heat-affected zone (CGHAZ), the intercritical heat-affected zone (ICHAZ) and the intercritically reheated coarse-grained heat-affected zone (ICCGHAZ), the toughness degradation should be minimized by design. Some of the means to prevent toughness degradation in these zones include, e.g., limiting the occurrence of coarse microstructural features, such as upper bainite, and controlling the amount of hard and brittle martensitic-austenitic constituents (MA) as well as coarse non-metallic inclusions that are known to be able to initiate cleavage cracks [3,4].

Acicular ferritic (AF) microstructure is usually viewed as beneficial in weld metal and $\mathrm{HAZ}$ due to an interlocking mechanism relative to crack propagation provided by its fine irregular microstructure. AF is known to nucleate on several inclusion types [5,6], the most prominent of them being $\mathrm{Ti}_{2} \mathrm{O}_{3}, \mathrm{TiO}_{2},(\mathrm{Ti}, \mathrm{Mn})_{2} \mathrm{O}_{3}, \mathrm{MnO}-\mathrm{Al}_{2} \mathrm{O}_{3}$ and their combinations with $\mathrm{MnS}$ and TiN as complex inclusions [5-10]. Approximations for the optimal inclusion size regarding the formation of AF have been reported to vary from 0.25 to $3 \mu \mathrm{m}[5,6,9]$. However, a maximum inclusion size of about $1 \mu \mathrm{m}$ is generally considered to be preferable due to coarse inclusions that typically degrade toughness properties [5]. Additionally, it has been reported that the density number of inclusions smaller than $2 \mu \mathrm{m}$ correlates with the fraction of AF [11].

In addition to inclusion characteristics, coarse prior austenite grain size (PAGS) is also known to promote the formation of AF by reducing the total grain boundary area and thus decreasing the fraction of grain boundary transformation products $[5,6]$. In the weld metals, the critical PAGS for the AF formation has been reported to vary between 20 and $60 \mu \mathrm{m}$ depending on boron alloying [12]. Boron inhibits the grain boundary ferrite transformation, thus decreasing the required critical PAGS [12]. In the CGHAZ, it has been suggested that PAGS should be coarser than $100 \mu \mathrm{m}$ in order to achieve more than $60 \%$ fraction of AF [13]. In another study, the formation of AF was observed when PAGS was larger than $250 \mu \mathrm{m}$ [7]. On the other hand, a PAGS coarser than $150 \mu \mathrm{m}$ has been suggested to diminish the positive effects of $\mathrm{AF}$ [5].

In addition to the optimal inclusion characteristics and sufficiently coarse PAGS, the third factor that affects the formation of AF is the cooling rate. The optimal cooling rate varies depending on the chemical composition of the steel. For instance, in low carbon steels, a cooling rate of $5^{\circ} \mathrm{C} / \mathrm{s}\left(t_{8 / 5} \approx 60 \mathrm{~s}\right)$ was observed to provide a large volume fraction of intragranular ferrite (IGF) that consists of intragranular polygonal ferrite (IPF) and intragranular acicular ferrite (IAF) $[14,15]$. According to another study, the fraction and lath length of $\mathrm{AF}$ in CGHAZ increases with increasing cooling time of up to a $t_{8 / 5}$ of $30 \mathrm{~s}$ [16]. Furthermore, in the case of Ti-deoxidized steels, AF has been detected even when the cooling time varies from $t_{8 / 5}=5.6$ to $1000 \mathrm{~s} \mathrm{[16]}$.

Generally, AF has been reported to improve the toughness of HAZ in a wide range of studies [8,17-22]. However, a sufficient fraction of AF in the microstructure is needed to enable its positive effects regarding toughness [23]. Additionally, aside from $\mathrm{AF}^{\prime}$ s other factors in the microstructure, such as inclusions [24-27], PAGS [21,28-32], residual austenite and/or martensite-austenite compounds [3,9,28,33-36], might have the opposite effect on the toughness of HAZ.

In the first part of the current study [37], it was concluded that the $\mathrm{MnO}-\mathrm{TiO}_{\mathrm{x}}-\mathrm{MnS}$ $(+\mathrm{TiN})$ type of inclusions together with coarsened PAGS readily promoted the formation of AF in the thermally simulated CGHAZ of the studied experimental steels. Additionally, the fraction of AF increased expectedly with an increasing cooling time from $800{ }^{\circ} \mathrm{C}$ to $500{ }^{\circ} \mathrm{C}$. In this second part of the research, we focused on the Charpy V-notch (CVN) impact toughness of the previously studied steels in order to clarify the effects of AF in the CGHAZ. Part of the study focused on instrumented CVN testing, which provides more detailed information about how different microstructures respond to crack initiation and propagation stages. The method has been utilized in recent years $[3,22,33,36,38,39]$, but the data are scarce overall. 


\section{Materials and Methods}

\subsection{Materials and Heat Treatments}

Three laboratory melts (denoted as Ref, $\mathrm{Ti}_{\text {low }}$ and $\mathrm{Ti}_{\text {high }}$ ) were cast in a vacuum induction furnace as $85 \mathrm{~kg}$ ingots; Table 1 lists their chemical compositions. After casting, the $75 \mathrm{~mm}$ thick slabs were soaked at $1200{ }^{\circ} \mathrm{C}$ in a laboratory furnace for $75 \mathrm{~min}$ and hot rolled to a thickness of $20 \mathrm{~mm}$ using approximately 23 pct reduction per pass, finishing around $1020^{\circ} \mathrm{C}$. After the final pass, the plates were cooled using water jet sprays to $540{ }^{\circ} \mathrm{C}$ and then cooled in air. The microstructures in the base material were ferritic, with some bainitic features and with mean grain sizes of $8.0 \mu \mathrm{m}, 7.2 \mu \mathrm{m}$ and $6.7 \mu \mathrm{m}$ in steels Ref, $\mathrm{Ti}_{\text {high }}$ and $\mathrm{Ti}_{\text {low }}$, respectively.

Table 1. Chemical compositions of the experimental laboratory steels (in wt.\%, the remainder being Fe) analyzed using optical emission spectrometry and combustion analysis techniques.

\begin{tabular}{ccccccccccccc}
\hline Steel & $\mathbf{C}$ & $\mathbf{S i}$ & $\mathbf{M n}$ & $\mathbf{P}$ & $\mathbf{S}$ & $\mathbf{A l}$ & $\mathbf{N b}$ & $\mathbf{V}$ & $\mathbf{T i}$ & $\mathbf{N}$ & $\mathbf{O}$ & Others \\
\hline Ref & 0.05 & 0.01 & 1.6 & 0.005 & 0.003 & 0.037 & 0.01 & 0.01 & 0.016 & 0.006 & 0.0023 & $\mathrm{Cr}, \mathrm{Mo}, \mathrm{Cu}$, \\
$\mathrm{Ti}_{\text {high }}$ & 0.05 & 0.03 & 1.7 & 0.005 & 0.003 & 0.002 & 0.01 & 0.07 & 0.027 & 0.006 & 0.0080 & $\mathrm{Ni}$ in equal \\
$\mathrm{Ti}_{\text {low }}$ & 0.05 & 0.23 & 1.7 & 0.007 & 0.003 & 0.003 & 0.01 & 0.07 & 0.016 & 0.008 & 0.0047 & proportions \\
\hline
\end{tabular}

A Gleeble 3800 thermomechanical machine was used for simulating the thermal cycle of an unaltered single-pass coarse-grained heat-affected zone (CGHAZ). The samples were cylindrical, with a length of $36 \mathrm{~mm}$ and a diameter of $6 \mathrm{~mm}$. The Rykalin 3D cooling model was used with the following parameters: a heating rate of $300{ }^{\circ} \mathrm{C} / \mathrm{s}$, a peak temperature of $1350{ }^{\circ} \mathrm{C}$, holding time of $0.1 \mathrm{~s}$ and free span at $9 \mathrm{~mm}$. The cooling times from 800 to $500{ }^{\circ} \mathrm{C}$ $\left(\mathrm{t}_{8 / 5}\right)$ were 5,24 and $64 \mathrm{~s}$, respectively. Once the samples cooled below $250^{\circ} \mathrm{C}$, they were removed from the machine and allowed to cool in the air to room temperature.

\subsection{Mechanical Testing}

The hardness profile was measured by using a Duramin-A300 (Struers) device under $100 \mathrm{~N}$ load $\left(\mathrm{HV}_{10}\right)$ on the center line of the surface of a section containing the transversal direction (TD) and the plate normal (i.e., thickness) direction (ND).

Standardized instrumented Charpy V-notch impact toughness tests (Zwick Roell PSW750 with TestXpertII software) according to ISO 14556 [40] were carried out at temperatures ranging from $-80^{\circ} \mathrm{C}$ to $-40{ }^{\circ} \mathrm{C}$ by using sub-sized $5 \times 10 \times 55 \mathrm{~mm}^{3}$ specimens that were oriented transverse to the rolling direction (T-L). Using the instrumented test, it is possible to determine the absorbed energy needed for the nucleation of the fracture crack as well as the energy needed for its propagation to complete the fracture.

\subsection{Microstructural Characterization}

General transformation microstructures in the simulated CGHAZ of Nital etched specimens were studied using a Zeiss Sigma field emission scanning electron microscope (FESEM) with an acceleration voltage of $5 \mathrm{kV}$ and a working distance of $5 \mathrm{~mm}$. The microstructural features were characterized using a Zeiss Sigma FESEM with an EDAX electron backscatter diffraction (EBSD) system with an acceleration voltage of $15 \mathrm{kV}$. The effective grain sizes were measured from the EBSD data (area $146 \times 146 \mu \mathrm{m}$; step size $0.3 \mu \mathrm{m})$. In order to mitigate the frequency of minuscule grains frequently encountered with EBSD, only grains with an equivalent circular diameter (ECD) larger than $0.55 \mu \mathrm{m}$ and misorientation greater than $15^{\circ}$ were used in the analysis. The EBSD image quality (IQ) analysis technique presented in [41,42] was used to deconvolute the IQ spectrum into quantitative microstructural features.

\subsubsection{Prior Austenite Reconstruction}

As revealing the PAGS using common metallography and etching techniques was practically impossible, MATLAB software supplemented with the MTEX toolbox [43] was 
utilized in order to reconstruct the prior austenite grains from the EBSD data. The reconstruction was carried out by two main steps on the basis of the previous works [44-46]. Firstly, the orientation relationship between the parent austenite and product ferritic phase, i.e., here mainly bainite, was determined using the Kurdjumov-Sachs $(\mathrm{K}-\mathrm{S})$ relationship [47] (i.e., $\{111\}_{\gamma} / /\{110\}_{\alpha}, 110_{\gamma} / / 111_{\alpha}$ ). Secondly, the grain map was divided into separate clusters, and parent austenite orientation was calculated for each cluster discretely in order to reconstruct the austenite orientation map and grain structure.

\subsubsection{Non-Metallic Inclusion Characterization}

The non-metallic inclusions on the polished cross-sections containing the rolling direction (RD) and the plate normal direction (ND) were characterized with JEOL JSM$7000 \mathrm{~F}$ FESEM. The measured area varied approximately between 30 and $40 \mathrm{~mm}^{2}$. The chemical composition for each detected inclusion was obtained with energy dispersive $X$-ray spectroscopy (EDS) in the Oxford Inca Feature runs by using an acceleration voltage of $15 \mathrm{kV}$ and a live time of $1 \mathrm{~s}$. Simultaneously, morphological data of each inclusion were recorded; here, the maximum length was used to depict their size. The minimum size for the inclusions to be included in the results was set to $1 \mu \mathrm{m}$.

The inclusions were classified in the same manner as in our previous work [37]. According to the EDS analyses, the phase composition of each inclusion was estimated, resulting in the calculated fractions of $\mathrm{Al}_{2} \mathrm{O}_{3}, \mathrm{MnO}, \mathrm{MnS}$, TiN and $\mathrm{TiO}_{2}$ components. In practice, inclusions can contain various titanium oxide phases, such as $\mathrm{TiO}_{2}$ or $\mathrm{Ti}_{2} \mathrm{O}_{3}$, but for the sake of simplicity, $\mathrm{TiO}_{x}$ was used to denote all variants. The inclusion classes were constructed based on a $10 \mathrm{wt} . \%$ threshold for the components, resulting in 31 combinations that were further combined into nine appropriate inclusion classes: $\mathrm{Al}_{2} \mathrm{O}_{3}$-containing

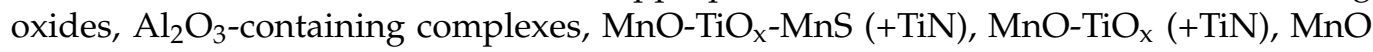
$(+\mathrm{MnS}-\mathrm{TiN}), \mathrm{TiO}_{\mathrm{x}}(+\mathrm{MnS}-\mathrm{TiN}), \mathrm{MnS}, \mathrm{MnS}-\mathrm{TiN}$ and TiN.

\subsubsection{Precipitate Characterization}

Qualitative and quantitative analyses of the precipitates within the CGHAZ of the simulated samples were investigated by using transmission electron microscopy (TEM) (JEOL JEM 2200FS EFTEM/STEM) at $200 \mathrm{kV}$ on different carbon extraction replicas. The carbon extraction replicas were prepared as illustrated in [48]. ImageJ software was employed to analyze 10 TEM images with the total investigated area of $100 \mu \mathrm{m}^{2}$ in order to determine the number density and mean ECD of the precipitates. Additionally, the precipitate size at $95 \%$ in the cumulative ECD distribution (D90\% $\%_{\mathrm{ppt}}$ ) was determined. The chemical composition and types of the precipitates were determined using EDS by analysis of at least 40 precipitates per condition on different carbon extraction replicas to obtain a reliable analysis. Furthermore, the crystallographic structure was determined using a TEM diffraction pattern.

\subsubsection{Retained Austenite Determination}

Rigaku SmartLab X-Ray diffractometer (XRD) with Co K $\alpha$ radiation was employed to determine the volume fraction of retained austenite. The operating conditions were an accelerating voltage of $40 \mathrm{kV}$, a current of $135 \mathrm{~mA}$, a scan speed of $7.1945^{\circ} / \mathrm{min}$, a step size of $0.05^{\circ}$ and a range of $45^{\circ}>2 \theta>130^{\circ}$. XRD data were treated by using whole profile Rietveld refinement analysis. The carbon content of retained austenite in wt.\% $(\mathrm{C} \gamma)$ was determined from the lattice parameter, i.e., $a=0.3578+0.0033 C \gamma$ [49], where $a(\mathrm{~nm})$ is the lattice parameter of retained austenite.

\section{Results and Discussion}

\subsection{Analysis of Toughness Testing}

The CVN absorbed energies of the CCHAZ of the studied steels are presented in Figure 1 , and a summary is provided in Table 2 . As can be observed, at $-40{ }^{\circ} \mathrm{C}$, testing was limited to specimens of $t_{8 / 5}=24 \mathrm{~s}$. At this temperature, all specimens had relatively high 
impact toughness, and the fracture occurred in a ductile mode. However, the absorbed energy in Ref specimens was statistically higher than in either of the Ti-deoxidized steels.

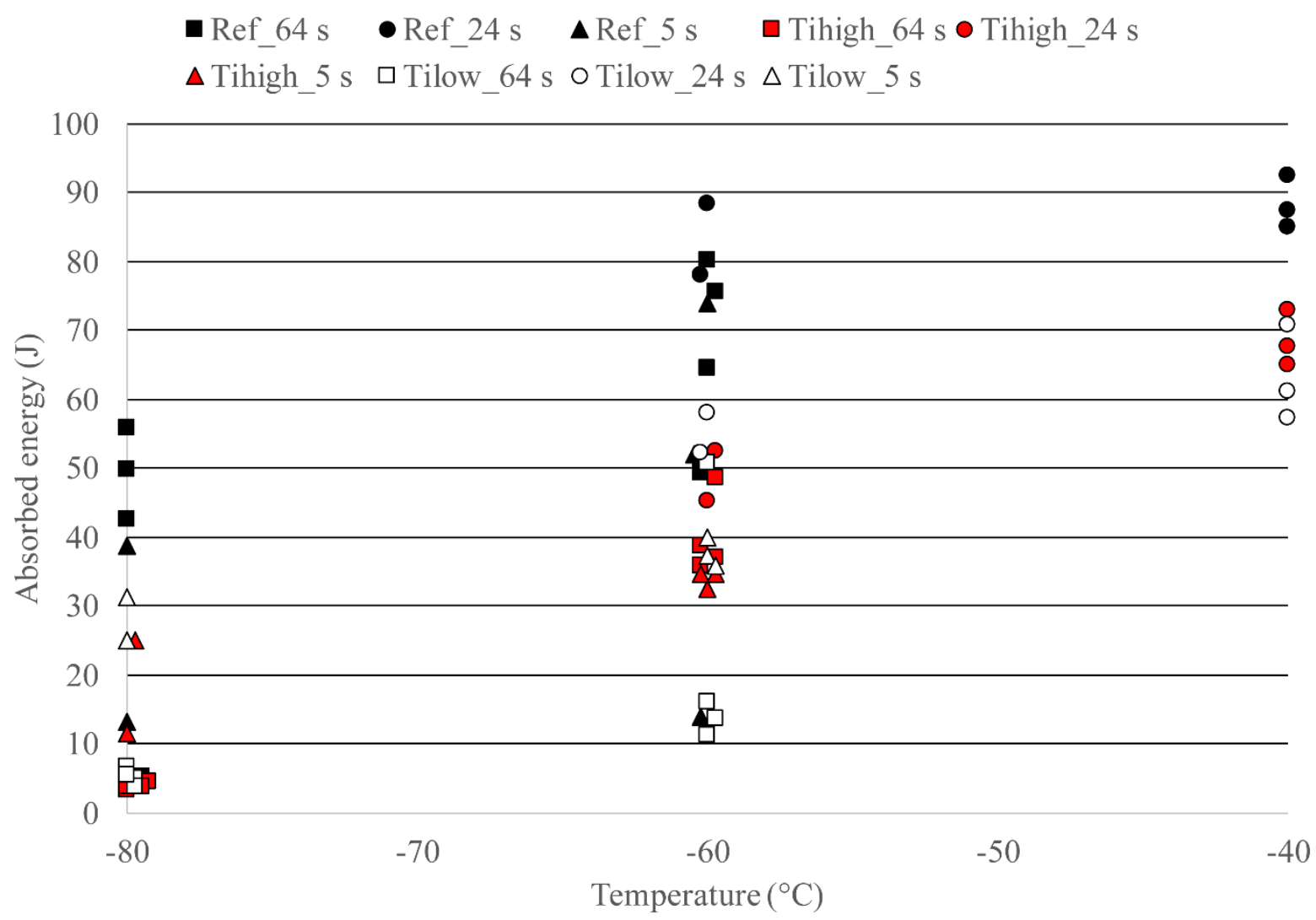

Figure 1. Impact toughness of the coarse-grained heat-affected zones (CGHAZ) in the studied steels tested at three temperatures (Sub-size Charpy V-notch $(\mathrm{CVN})$ specimens, $5 \times 10 \times 55 \mathrm{~mm}$ ).

Table 2. Summary of the CVN data (absolute energy values).

\begin{tabular}{ccccc}
\hline Cooling Time (s) & $\mathbf{T e m p}\left({ }^{\circ} \mathbf{C}\right)$ & $\operatorname{Ref}(\mathbf{J})$ & $\operatorname{Ti}_{\text {high }}(\mathbf{J})$ & Ti $_{\text {low }}(\mathbf{J})$ \\
\hline \multirow{2}{*}{5} & -60 & $47 \pm 30$ & $34 \pm 1$ & $38 \pm 2$ \\
\cline { 2 - 5 } & -80 & $26 \pm 18$ & $19 \pm 9$ & $28 \pm 4$ \\
\hline \multirow{2}{*}{24} & -40 & $89 \pm 4^{*}$ & $69 \pm 4$ & $63 \pm 7$ \\
\cline { 2 - 5 } & -60 & $83 \pm 7$ & $49 \pm 6$ & $55 \pm 4$ \\
\hline \multirow{2}{*}{64} & -60 & $68 \pm 14^{*}$ & $40 \pm 6$ & $23 \pm 19$ \\
\hline
\end{tabular}

${ }^{*}$ Denotes statistical difference (Mood's Median Test, $p<0.05$ ).

At $-60{ }^{\circ} \mathrm{C}$, the Ref specimens, regardless of the cooling time, showed higher impact toughness values compared to those of Ti-deoxidized variants. In particular, the $\mathrm{Ti}_{\mathrm{low}}$ with $t_{8 / 5}=64 \mathrm{~s}$ showed poor performance. Similar trends were observed at $-80{ }^{\circ} \mathrm{C}$, i.e., the Ref specimens had gradually lower values, but they were still higher on average than those of the other variants. The lowest energies were observed again in Ti-deoxidized specimens with $t_{8 / 5}=64 \mathrm{~s}$. However, the differences were not statistically significant due to inherent scatter in values in the ductile-brittle transition range.

The CVN results were largely unexpected since, based on our previous work [37], the Ti-deoxidized steels and especially $\mathrm{Ti}_{\text {low }}$ were expected to have an increasing fraction of $\mathrm{AF}$ in the microstructure along with increasing cooling time, which, in turn, is often associated with improved toughness performance. Conversely, here, the highest toughness was consistently achieved in the Al-deoxidized reference steel and $\mathrm{Ti}_{\text {low }}$, with the longest 
cooling time showing the lowest toughness. The subsequent chapters aim to elucidate the reasons for this behavior.

The typical load-displacement curves obtained from the instrumented Charpy-V tests are presented in Figure 2. The graphs illustrate the differences between the materials, with the Ref specimens having higher displacement, and the total area of the curves compared with the Ti-deoxidized specimens. Three distinct types of curves were observed in the results: (i) completely brittle behavior, where the onset of brittle fracture occurs when the $\mathrm{F}_{\mathrm{m}}$ is reached; (ii) mixture of ductile and brittle fractures, in which the ductile propagation phase occurs after the $F_{m}$ and is followed by brittle fracture; and (iii) ductile and brittle propagation followed by crack arrest and ductile fracture. All the materials exhibited the ability for crack arrest after brittle propagation at $-40{ }^{\circ} \mathrm{C}\left(t_{8 / 5}=24 \mathrm{~s}\right)$, as observed in Figure 2c. However, at $-60^{\circ} \mathrm{C}$, the fracture type shifted to brittle fracture in the Tideoxidized specimens. At $t_{8 / 5}=5 \mathrm{~s}$, the ductile propagation phase was virtually absent, whereas a clear ductile region was observed in the specimens with cooling times of $24 \mathrm{~s}$ and $64 \mathrm{~s}$. At $-80{ }^{\circ} \mathrm{C}$, brittle fracture occurred as $\mathrm{F}_{\mathrm{m}}$ was reached in the $\mathrm{Ti}_{\text {low }}$ and $\mathrm{Ti}_{\text {high }}$ specimens, and it was more pronounced in the $t_{8 / 5}=64 \mathrm{~s}$ specimens where extremely low values of displacement were obtained. The Ref specimens demonstrated similar behavior with $t_{8 / 5}=5 \mathrm{~s}$, while a clear ductile zone was observed in the $t_{8 / 5}=64 \mathrm{~s}$ specimens, as evidenced by the higher total absorbed impact energy.

The distribution of total energy absorbed during the impact test at $-60{ }^{\circ} \mathrm{C}$ is presented in Table 3. The fractions of energy absorbed in the crack initiation, crack propagation and crack arrest phases are denoted as $E_{i}, E_{p}$ and $E_{a}$, respectively. $E_{i}$ is determined from start to $\mathrm{F}_{\mathrm{m}}, E_{p}$ from $\mathrm{F}_{\mathrm{m}}$ to the onset of brittle crack propagation and $E_{a}$ from crack arrest to complete fracture. The majority of the Ref specimens demonstrated $E_{i}$ values between 25 and $35 \mathrm{~J}$. The corresponding values for the Ti-deoxidized specimens were similar (23-33 J), except for the $\mathrm{Ti}_{\text {low }}$ specimens with $t_{8 / 5}=64 \mathrm{~s}$ showing initiation energies in the range of 11-28 J. More noticeable differences were observed in the propagation energy $E_{p}$. In Ref steel, $\mathrm{E}_{\mathrm{p}}$ was higher than $E_{i}$ in most cases. On the contrary, $E_{i}$ was higher than $E_{p}$ in every specimen of the Ti-deoxidized steels. Notable amounts of $E_{a}$ were only observed on Ref specimens.

Table 3. Instrumented CVN data of the samples tested at $-60^{\circ} \mathrm{C}$.

\begin{tabular}{ccccccccccc}
\hline & \multicolumn{3}{c}{ Ref } & \multicolumn{3}{c}{$\mathbf{T i}_{\text {high }}$} & \multicolumn{3}{c}{$\mathbf{T i}_{\text {low }}$} \\
\cline { 2 - 11 } Cooling Time (s) & $\boldsymbol{E}_{\boldsymbol{i}}$ & $\boldsymbol{E}_{\boldsymbol{p}}$ & $\boldsymbol{E}_{\boldsymbol{a}}$ & $\boldsymbol{E}_{\boldsymbol{i}}$ & $\boldsymbol{E}_{\boldsymbol{p}}$ & $\boldsymbol{E}_{\boldsymbol{a}}$ & $\boldsymbol{E}_{\boldsymbol{i}}$ & $\boldsymbol{E}_{\boldsymbol{p}}$ & $\boldsymbol{E}_{\boldsymbol{a}}$ \\
& $(\mathbf{J})$ & $\mathbf{( J )}$ & $\mathbf{( J )}$ & $\mathbf{( J )}$ & $\mathbf{( J )}$ & $\mathbf{( J )}$ & $(\mathbf{J})$ & $(\mathbf{J})$ & $(\mathbf{J})$ \\
\hline 5 & 29 & 19 & 4 & 26 & 7 & 0 & 37 & 10 & 1 \\
5 & 13 & 0 & 0 & 26 & 9 & 0 & 29 & 6 & 1 \\
5 & 32 & 34 & 8 & 25 & 9 & 1 & 26 & 13 & 1 \\
24 & 37 & 52 & 0 & 28 & 17 & 0 & 33 & 19 & 0 \\
24 & 33 & 40 & 5 & 29 & 24 & 0 & 33 & 25 & 0 \\
64 & 25 & 24 & 0 & 24 & 15 & 0 & 11 & 0 & 0 \\
64 & 30 & 46 & 4 & 27 & 21 & 0 & 16 & 0 & 0 \\
64 & 30 & 33 & 1 & 23 & 14 & 0 & 14 & 0 & 0 \\
64 & 29 & 43 & 4 & 29 & 6 & 0 & 28 & 22 & 0 \\
\hline
\end{tabular}

Clear differences are observed between Ref and Ti-deoxidized steels in the loaddisplacement graphs. The Ref specimens have higher total displacement due to a higher fraction of ductile fracture, whereas crack initiation in the Ti-deoxidized steels resulted in brittle failure more often immediately after reaching the peak load. In addition, Ref specimens showed better crack arrestability and, therefore, considerably higher total displacements. The results for $\mathrm{Ti}_{\text {high }}$ and $\mathrm{Ti}_{\text {low }}$ were similar for $t_{8 / 5}$ of 5 and $24 \mathrm{~s}$, but it was considerably lower for $\mathrm{Ti}_{\text {low }}$ at $64 \mathrm{~s}$. These results suggest that the CGHAZ microstructure of the Ti-killed steels is less effective in impeding the propagation of the crack than that of the Ref steel. Microstructure characteristics such as grain boundary misorientations can 
have a decisive effect on the propagation of the crack. A fine grain size with a large fraction of high angle grain boundaries provides more obstacles to hinder the propagation of the crack. Additionally, with the differences between the deoxidizing treatments, the inclusion structures may differ from one another. In particular, if the density of large inclusions is higher, there exist more potential sites for brittle fracture initiation.
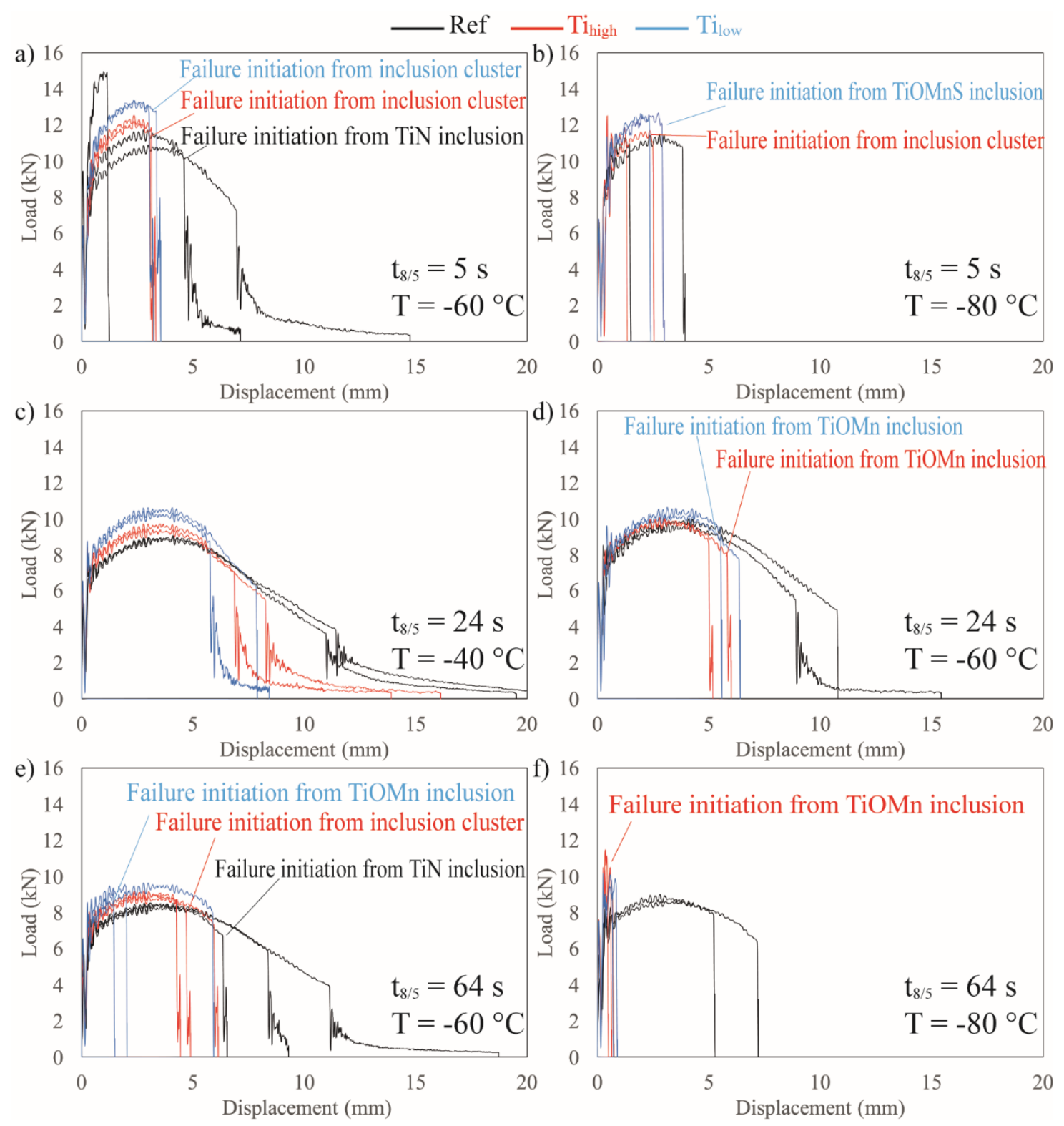

Figure 2. Load-displacement curves obtained from the instrumented CVN tests. CGHAZ simulated with $t_{8 / 5}=5 \mathrm{~s}$ tested at $-60{ }^{\circ} \mathrm{C}$ (a) and $-80{ }^{\circ} \mathrm{C}(\mathbf{b}) ; t_{8 / 5}=24 \mathrm{~s}$ tested at $-40{ }^{\circ} \mathrm{C}(\mathbf{c})$ and $-60{ }^{\circ} \mathrm{C}(\mathbf{d})$; and $t_{8 / 5}=64 \mathrm{~s}$ tested at $-60{ }^{\circ} \mathrm{C}(\mathbf{e})$ and $-80^{\circ} \mathrm{C}(\mathbf{f})$.

\subsection{Hardness Differences in Simulated CGHAZ}

The average hardnesses measured from the simulated CGHAZ of each studied steel using different cooling times are presented in Figure 3. Supplementary hardness measurements were also carried out for CGHAZ specimens simulated using $t_{8 / 5}=17 \mathrm{~s}$, as well as immediate water quenching from peak temperature $\left(t_{8 / 5} \approx 2-3 \mathrm{~s}\right)$. It can be observed that the hardness decreases monotonously with increasing cooling time in each steel. Additionally, the hardness of the simulated CGHAZ for all the conditions is the lowest in Ref and highest in $\mathrm{Ti}_{\text {low }}$. As the value of hardness is related to that of the tensile strength, 
higher values may explain some differences in the impact toughness. Ref steel had the best impact toughness with any of the applied cooling times and in any tested temperature (Figure 1), and CGHAZ was lower in hardness compared to Ti-deoxidized steels with any cooling time.

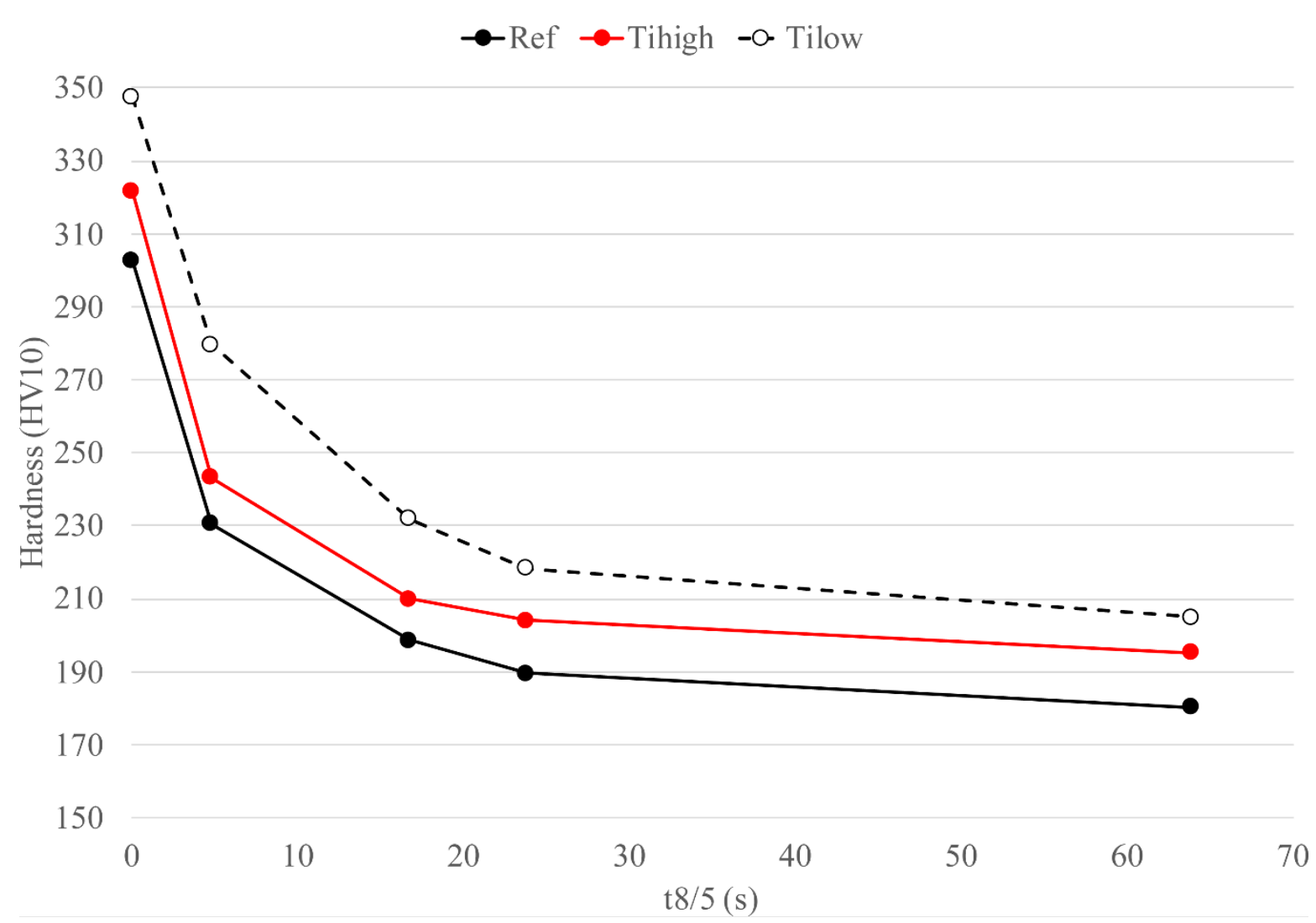

Figure 3. Average hardness measured from the simulated CGHAZ of the three materials with cooling times of $t_{8 / 5} \approx 2-3 \mathrm{~s}$ (water quenched), $5 \mathrm{~s}, 17 \mathrm{~s}, 24 \mathrm{~s}$ and $64 \mathrm{~s}$.

The hardness differences originate from the compositional differences. Carbon content often has a direct correlation to hardness, but these steels had comparable carbon contents $(0.05 \%)$. Therefore, the differences are related to other alloying elements affecting hardenability. Vanadium, a potent hardening agent in the microalloying range was $0.07 \%$ in $\mathrm{Ti}_{\text {high }}$ and $\mathrm{Ti}_{\text {low }}$, while Ref only had a trace amount $(0.01 \%)$ of $\mathrm{V}$. Additionally, a minor increase in hardenability could be attributed to silicon content, which was higher in $\mathrm{Ti}_{\text {low }}$ $(0.23 \%)$ compared to $\mathrm{Ti}_{\text {high }}(0.03 \%)$ and $\operatorname{Ref}(0.01 \%)$.

\subsection{Role of Cooling Time}

\subsubsection{Microstructural Characterization}

General microstructural images of the studied steels with the shortest and longest applied cooling times are presented in Figure 4 . With a short cooling time $\left(t_{8 / 5}=5 \mathrm{~s}\right)$, the microstructure transformation of each steel appeared to mainly have relatively fine lathlike bainitic features, while with a longer cooling time $\left(t_{8 / 5}=64 \mathrm{~s}\right)$, the microstructures were coarse, less hardened and consisted of plate-like bainitic features as well as ferrite. Acicular ferrite can be observed to have nucleated from nearby inclusions. 

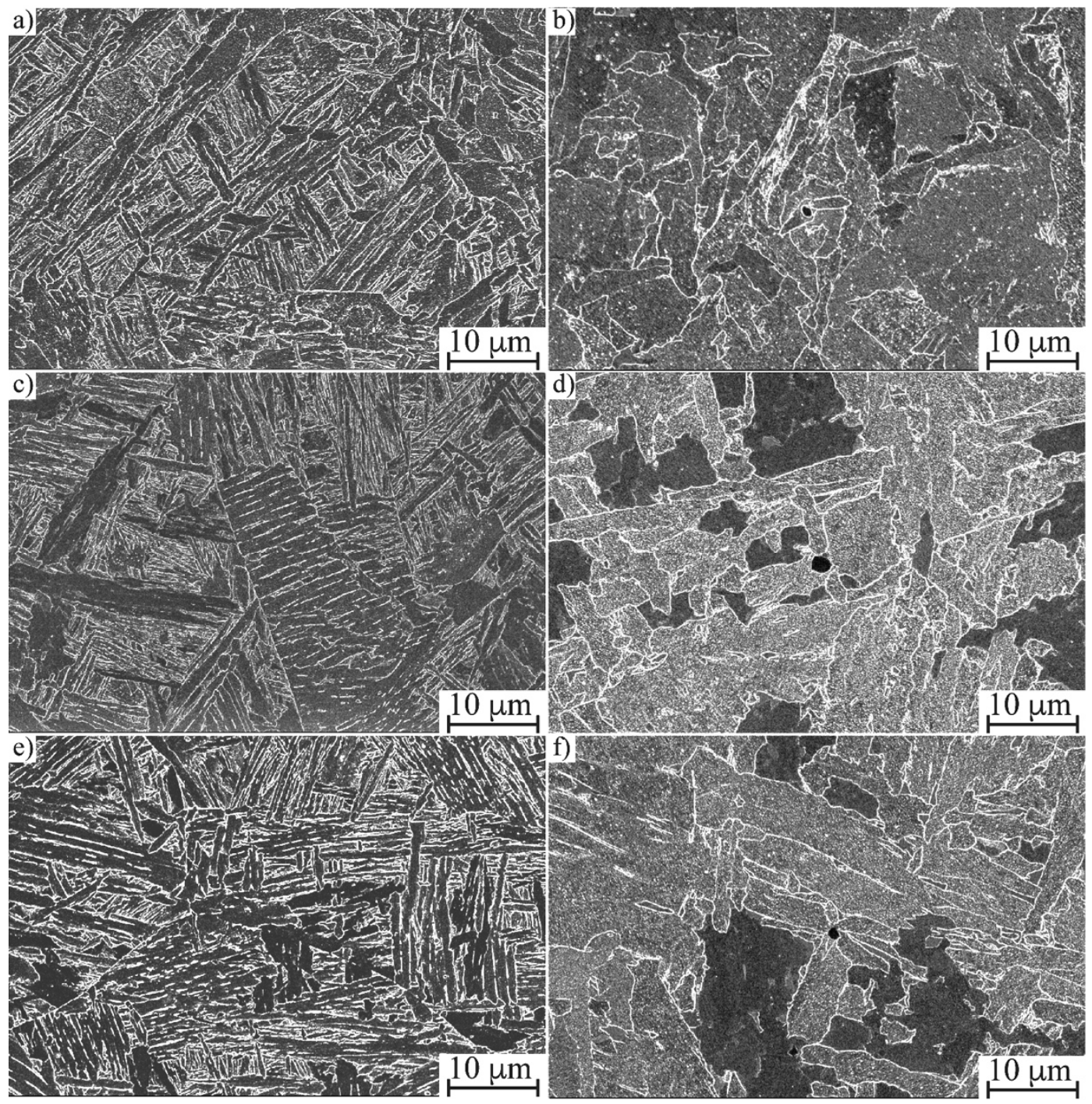

Figure 4. Field emission scanning electron microscope (FESEM) images of the microstructure in the simulated CGHAZ of Ref, $\mathrm{Ti}_{\text {high }}$ and $\mathrm{Ti}_{\text {low }}$ with $t_{8 / 5}=5 \mathrm{~s}(\mathbf{a}, \mathbf{c}, \mathbf{e})$ and $t_{8 / 5}=64 \mathrm{~s}(\mathbf{b}, \mathbf{d}, \mathbf{f})$, respectively.

\subsubsection{Phase Fractions}

The detailed fractions of different microstructural phases in the studied steels with $t_{8 / 5}=5 \mathrm{~s}$ and $24 \mathrm{~s}$ have been presented in a previous paper and are not reproduced here [37]. However, the phase fractions of $t_{8 / 5}=64 \mathrm{~s}$ that were obtained similarly by IQ analysis are presented in Figure 5. The phase fractions of all the studied variants are gathered in Table 4.

Table 4. Fractions of different microstructures (\%) in the simulated CGHAZ of the studied steels obtained by IQ analysis as well as the volume fraction of retained austenite (RA) (\%) and C-content in austenite (wt\%) obtained by X-ray diffraction (XRD).

\begin{tabular}{|c|c|c|c|c|c|c|c|c|c|}
\hline Microstructure & $\begin{array}{c}\text { Ref } \\
5 \mathrm{~s}\end{array}$ & $\begin{array}{c}\mathrm{Ti}_{\text {high }} \\
5 \mathrm{~s}\end{array}$ & $\begin{array}{c}\mathbf{T i}_{\text {low }} \\
5 \mathrm{~s}\end{array}$ & $\begin{array}{l}\text { Ref } \\
24 \mathrm{~s}\end{array}$ & $\begin{array}{c}\mathrm{Ti}_{\text {high }} \\
24 \mathrm{~s}\end{array}$ & $\begin{array}{c}\mathrm{Ti}_{\text {low }} \\
24 \mathrm{~s}\end{array}$ & $\begin{array}{l}\text { Ref } \\
64 \mathrm{~s}\end{array}$ & $\begin{array}{c}\text { Ti }_{\text {high }} \\
64 \mathrm{~s}\end{array}$ & $\begin{array}{c}\mathrm{Ti}_{\text {low }} \\
64 \mathrm{~s}\end{array}$ \\
\hline Acicular Ferrite & - & - & 19 & - & - & 28 & 13 & 22 & 46 \\
\hline Plate-Like Bainite & 44 & 50 & 44 & 60 & 64 & 52 & 66 & 65 & 28 \\
\hline Lath Bainite & 13 & 21 & 32 & 15 & 8 & 13 & 15 & 8 & 15 \\
\hline Polygonal Ferrite & 3 & 1 & 4 & 3 & 6 & 6 & 4 & 4 & 8 \\
\hline Granular Bainite & 35 & 22 & - & 20 & 22 & - & - & - & - \\
\hline Martensite & 6 & 7 & 2 & 3 & 2 & 2 & 3 & 2 & 3 \\
\hline Retained Austenite * & $1.48 \pm 0.06$ & $2.02 \pm 0.07$ & $2.30 \pm 0.07$ & $1.59 \pm 0.06$ & $2.97 \pm 0.16$ & $4.02 \pm 0.12$ & $1.14 \pm 0.04$ & $3.45 \pm 0.05$ & $3.38 \pm 0.04$ \\
\hline $\mathrm{C} \gamma$ & 1.07 & 0.94 & 0.56 & 0.83 & 0.95 & 1.07 & 1.05 & 1.02 & 0.92 \\
\hline
\end{tabular}

${ }^{*}$ Error values are the standard deviation of the population. 

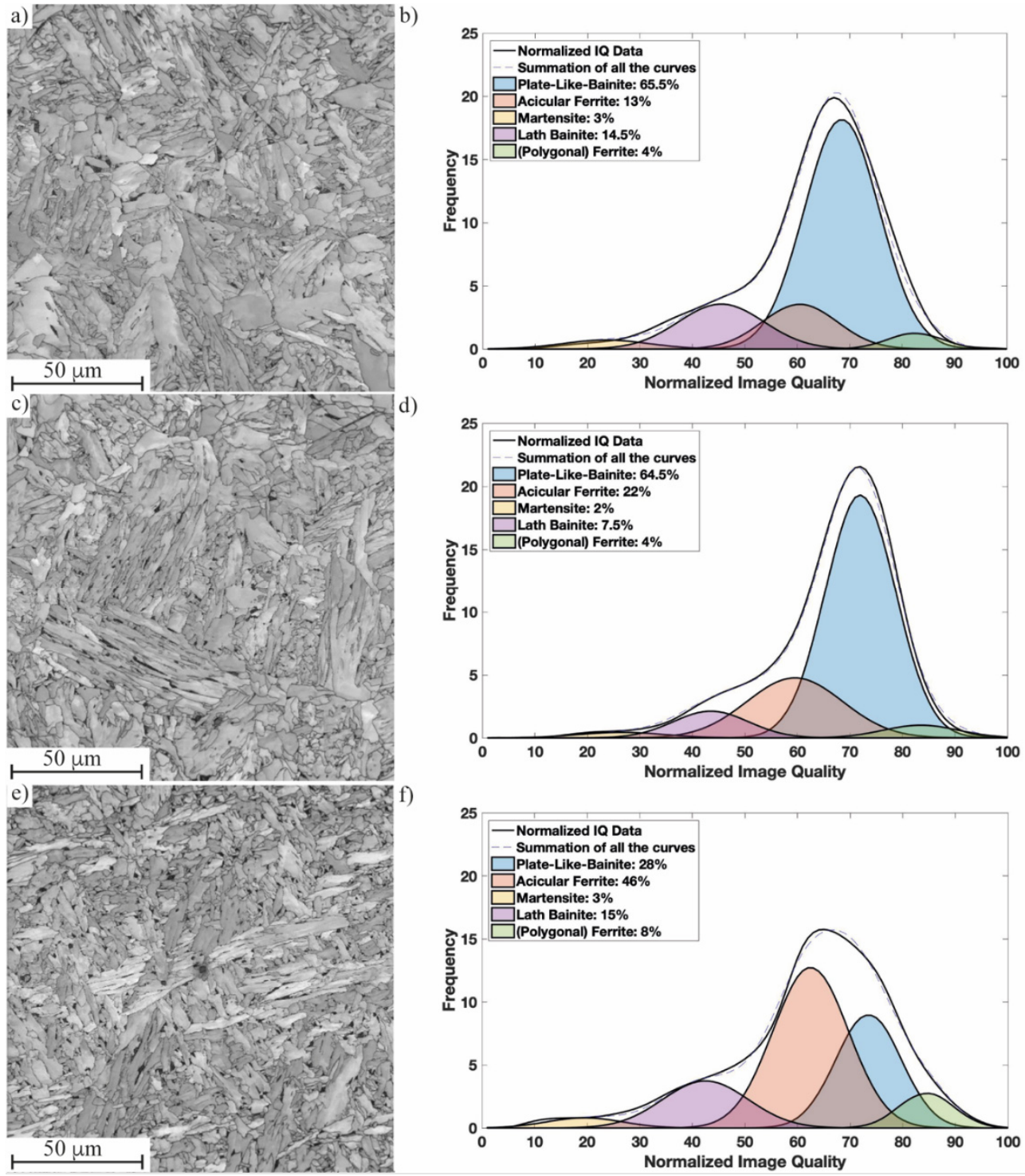

Figure 5. Electron backscatter diffraction (EBSD) image of the microstructure with the corresponding image quality (IQ) analysis of the phase fractions of the simulated CGHAZ with $t_{8 / 5}=64$ s in steels: $\operatorname{Ref}(\mathbf{a}, \mathbf{b}) ; \mathrm{Ti}_{\text {high }}(\mathbf{c}, \mathbf{d})$; and $\mathrm{Ti}_{\text {low }}(\mathbf{e}, \mathbf{f})$.

When the cooling time from $800{ }^{\circ} \mathrm{C}$ to $500{ }^{\circ} \mathrm{C}$ was extended to $64 \mathrm{~s}$, AF was detected also in $\mathrm{Ti}_{\text {high }}$ in small amounts and even in Ref. In $\mathrm{Ti}_{\text {low }}, \mathrm{AF}$ was also observed with shorter cooling times, but at $64 \mathrm{~s}$, its fraction had already increased to $46 \%$ of the microstructure. The reasons for the occurrence of AF in this steel and not in the other two have been discussed in prior works and were concluded to be due to coarser prior austenite grains and overall favorable inclusions for AF formation. The increasing fraction of AF could be generally expected to improve the toughness. However, in the present study, $\mathrm{Ti}_{\text {low }}$ had the weakest impact toughness and even the increasing fraction of AF along the increasing cooling time did not appear to be beneficial. It is still possible that, even in the case with the highest fraction of $\mathrm{AF}$, there still was not enough $\mathrm{AF}$ in order to improve impact toughness.

The volume fraction of retained austenite (RA) in the studied steels obtained by XRD is also presented in Table 4. The fraction of RA was relatively low in all variants, and it was the lowest in the Ref specimens. The presence of RA may indicate martensite-austenite (M-A) islands, which are known to deteriorate toughness in HAZ [31,34,50].

For the sake of comparison, the fraction of RA was also determined by EBSD. The results (in \%) were $0.2,0.3$ and 0.2 . at $t_{8 / 5}=5 \mathrm{~s}$ and $0.4,0.5$ and 1.0 at $t_{8 / 5}=64 \mathrm{~s}$ in Ref, Ti $\mathrm{i}_{\text {high }}$ 
and $\mathrm{Ti}_{\text {low }}$, respectively. Due to the difference in the characterization method, the fraction of RA is clearly lower than was observed with XRD. However, the trend is the same that the slower cooling time slightly increases the fraction of RA; moreover, in Ti-deoxidized steels, there is a slightly higher fraction of RA than in the Al-deoxidized reference steel.

Figure 6, based on the EBSD data, shows the occurrence and shape of RA in the simulated CGHAZ of $\mathrm{Ti}_{\text {low }}$ with $t_{8 / 5}=64 \mathrm{~s}$ where the highest fraction of RA was detected.
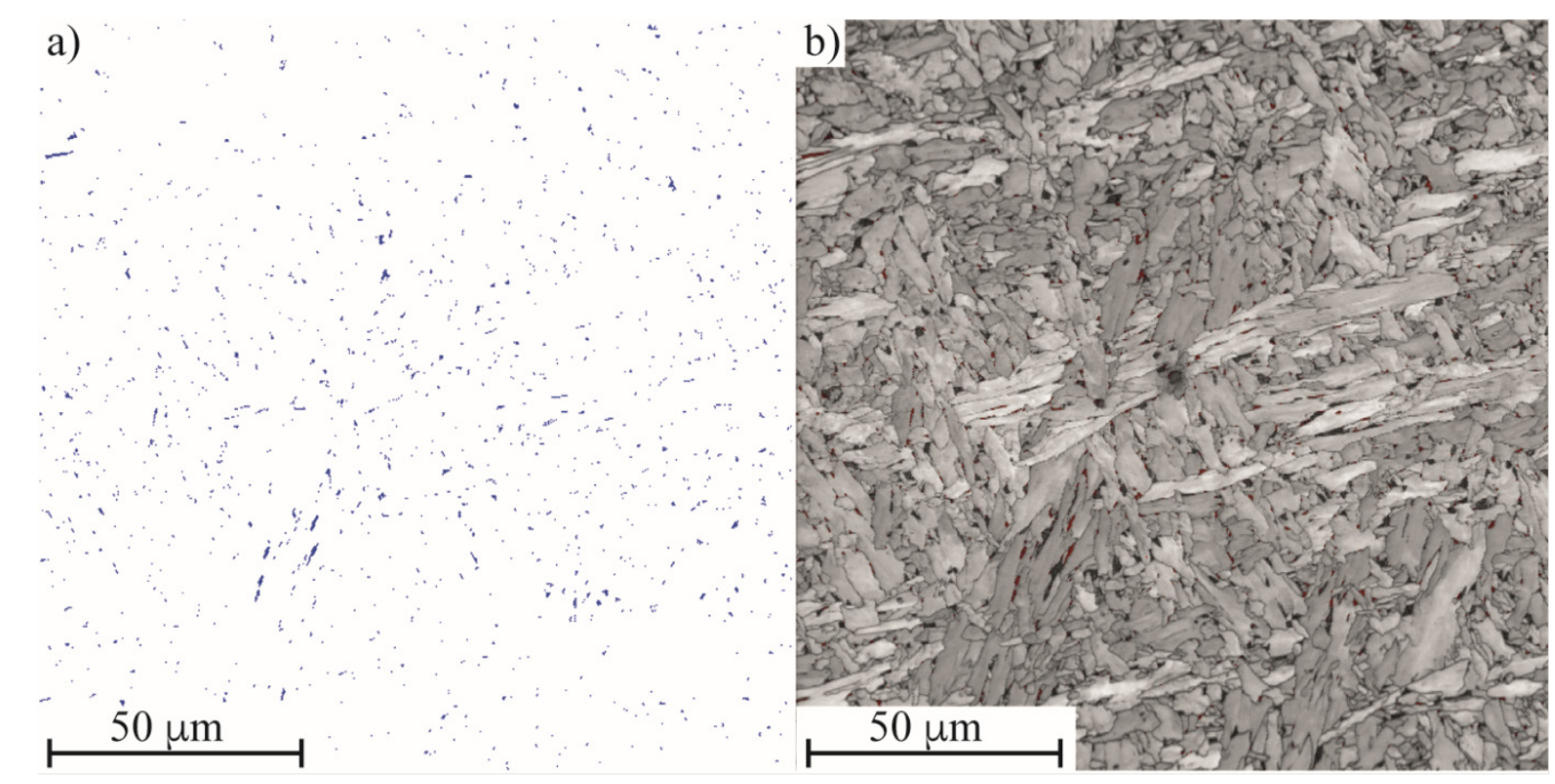

Figure 6. Retained austenite in the ferrite matrix (a) and its location within the grains (b) in the simulated CGHAZ of Ti $\mathrm{l}_{\text {low }}$ with $t_{8 / 5}=64 \mathrm{~s}$. Blue color indicates RA in (a) and red in (b).

\subsubsection{Role of Prior Austenite Grain Size}

Reconstructed prior austenite grains in the CGHAZ were presented in the authors' previous paper [37] where, after holding samples at $1350^{\circ} \mathrm{C}$ for $2 \mathrm{~min}$ and water quenching, the PAGS in Ref, $\mathrm{Ti}_{\text {high }}$ and $\mathrm{Ti}_{\text {low }}$ was $75 \mu \mathrm{m}, 77 \mu \mathrm{m}$ and $125 \mu \mathrm{m}$, respectively. The coarse PAGS is known to decrease toughness [31], even if also promoting AF formation [5,6]. However, the coarser PAGS in $\mathrm{Ti}_{\text {low }}$ compared to the other studied steels may partly explain the deteriorated impact toughness.

\subsubsection{Effective Grain Size}

The grain sizes had non-normal distributions, so the median, 95th percentile and $80 \%$ cumulative grain sizes were used in the comparisons in Table 5. Generally, the median varied from 1.04 to $2.44 \mu \mathrm{m}$, and the longer cooling time coarsened the largest grains. With $t_{8 / 5}=5 \mathrm{~s}$, both the coarsest grains and the median were finer in $\mathrm{Ti}_{\text {low }}$ compared to other steels $\left(p<0.05\right.$, Mann-Whitney). In intermediate $t_{8 / 5}=24 \mathrm{~s}$, there were statistical differences, except between Ref and $\mathrm{Ti}_{\text {low }}$. In the slowest cooling scenario, $t_{8 / 5}=64 \mathrm{~s}$, the grain sizes were finest in $\mathrm{Ti}_{\text {low }}$, and no statistical difference was observed between Ref and $\mathrm{Ti}_{\text {high. }}$. Interestingly, the median grain size of the latter was the finest overall. However, the 95th percentile and D80\% cumulative grain sizes were on the large side, with both $t_{8 / 5}=24 \mathrm{~s}$ and $64 \mathrm{~s}$.

Since the finer grain size is known to improve the toughness, the deteriorated impact toughness of Ti-deoxidized steels with $t_{8 / 5}=64 \mathrm{~s}$ may be due to the number of coarse grains. However, in Ref, the coarser grain size in the case of $t_{8 / 5}=64 \mathrm{~s} \mathrm{compared} \mathrm{to} \mathrm{shorter}$ cooling times does not appear to lower impact toughness, and especially at $-80{ }^{\circ} \mathrm{C}$, the best impact toughness was measured in Ref with $t_{8 / 5}=64 \mathrm{~s}$. 
Table 5. Median, 95th percentile and grain size at $80 \%$ in the cumulative grain size distribution of the studied steels with $t_{8 / 5}=5 \mathrm{~s}, 24 \mathrm{~s}$ and $64 \mathrm{~s}$.

\begin{tabular}{|c|c|c|c|c|c|c|c|c|c|}
\hline Data Type & $\begin{array}{c}\text { Ref } \\
5 \mathrm{~s}\end{array}$ & $\begin{array}{c}\mathrm{Ti}_{\text {high }} \\
5 \mathrm{~s}\end{array}$ & $\begin{array}{c}\mathbf{T i}_{\text {low }} \\
5 \mathrm{~s}\end{array}$ & $\begin{array}{l}\text { Ref } \\
24 \text { s }\end{array}$ & $\begin{array}{c}\mathrm{Ti}_{\text {high }} \\
24 \mathrm{~s}\end{array}$ & $\begin{array}{c}\mathbf{T i}_{\text {low }} \\
24 \text { s }\end{array}$ & $\begin{array}{l}\text { Ref } \\
64 \mathrm{~s}\end{array}$ & $\begin{array}{c}\mathrm{Ti}_{\text {high }} \\
64 \mathrm{~s}\end{array}$ & $\begin{array}{c}\mathrm{Ti}_{\text {low }} \\
64 \mathrm{~s}\end{array}$ \\
\hline Median $(\mu \mathrm{m})$ & 1.54 & 1.37 & 1.26 & 1.84 & 2.44 & 1.61 & 1.37 & 1.93 & 1.04 \\
\hline 95th percentile $(\mu \mathrm{m})$ & 8.76 & 8.54 & 6.27 & 15.40 & 15.62 & 11.22 & 14.15 & 14.19 & 10.39 \\
\hline $\mathrm{D} 80 \%(\mu \mathrm{m})$ & 14.27 & 11.20 & 8.92 & 21.71 & 20.71 & 17.49 & 20.66 & 23.05 & 22.08 \\
\hline
\end{tabular}

\subsection{Role of Inclusions}

Figure 7 presents the number densities and area fractions of the different classes of inclusions in each of the studied variants according to the classification scheme used. The majority of the inclusions in $\mathrm{Ti}_{\text {high }}$ and $\mathrm{Ti}_{\text {low }}$ contained $\mathrm{TiO}_{\mathrm{x}}$, while inclusions containing considerable amounts of TiN were common only found in the Ref and $\mathrm{Ti}_{\text {high }}$ samples. However, in $\mathrm{Ti}_{\text {low }}$ samples, TiN was present together with MnS in MnS-TiN inclusions. A high number of $\mathrm{Al}_{2} \mathrm{O}_{3}$-containing inclusions in the Ref sample indicates the differences in deoxidation practice.

When it comes to the sizes of the inclusions, it is evident that in the Ref and $\mathrm{Ti}_{\text {low }}$ samples, less than one-third of inclusions are larger than $3 \mu \mathrm{m}$, whereas the corresponding fraction in the $\mathrm{Ti}_{\text {high }}$ samples is almost $50 \%$. The area fractions of inclusions in Figure $7 \mathrm{~b}$ suggest that both coarse inclusions and all inclusions have the highest area fraction in $\mathrm{Ti}_{\text {high }}$ samples, followed by $\mathrm{Ti}_{\text {low }}$ and Ref. This is in line with the total oxygen contents of the steels that were $23 \mathrm{ppm}$ in the Al-deoxidized Ref, whereas the Ti-deoxidized steels had levels of 47 and $80 \mathrm{ppm}$ in $\mathrm{Ti}_{\text {low }}$ and $\mathrm{Ti}_{\text {high }}$, respectively. Between the samples of different cooling times, there were no remarkable differences, which was expected since inclusions have already formed during the manufacturing processes, and in all cases, the time occurrence at a high temperature is relatively too short to cause changes in inclusion contents.

Inclusions coarser than $3 \mu \mathrm{m}$ are presented separately since coarser inclusions are known to be more harmful to the toughness and ductility of steels than smaller ones. The beneficial inclusions regarding AF formation should be those consisting of $\mathrm{MnO}^{-\mathrm{TiO}_{x}}$

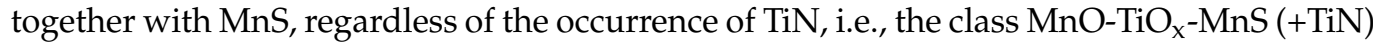
in Figure 7, as was suggested in a prior study [37]. However, the inclusion size should remain modest enough to prevent their detrimental effect on toughness and ductility. In Ti-deoxidized steels, the majority of the inclusions coarser than $3 \mu \mathrm{m}$ were $\mathrm{MnO}-\mathrm{TiO}_{\mathrm{x}}$ $(+\mathrm{TiN})$. However, in $\mathrm{Ti}_{\text {high }}$, their number was approximately twice that of $\mathrm{Ti}_{\text {low }}$. In $\mathrm{Ti}_{\text {high }}$, among the coarse inclusions, there was also TiN, which is known to be extremely harmful to toughness [24,26]. In the Ref material, the coarse inclusions consisted mainly of $\mathrm{Al}_{2} \mathrm{O}_{3}$ containing complex inclusions as well as MnS, but some TiN was also observed. The number of coarse inclusions in Ref was approximately the same as in $\mathrm{Ti}_{\mathrm{low}}$, but the area fraction of coarse inclusions was slightly higher in $\mathrm{Ti}_{\text {low }}$ than in Ref, indicating the inclusion mean size as being coarser in $\mathrm{Ti}_{\text {low }}$.

Since the fractography studies (presented later in Section 3.6) indicated the fracture initiators to be TiN in Ref and mainly $\mathrm{TiO}_{x}$-containing inclusions in Ti-deoxidized steels, it can be understood that these are the most detrimental inclusion types in these steels regarding impact toughness. In Ti-deoxidized steels, it appears to be logical since $\mathrm{TiO}_{x^{-}}$ containing inclusions form the majority of all the coarse inclusions. The higher number of these inclusions in $\mathrm{Ti}_{\mathrm{high}}$ compared to the other studied steels could be attributed to the relatively low impact toughness of this steel. On the other hand, the weakest impact toughness was observed in the $\mathrm{Ti}_{\text {low }}$ that actually has less coarse inclusions than $\mathrm{Ti}_{\text {high }}$ and approximately the same number as in the Ref that had the best impact toughness of the studied steels. 
a)

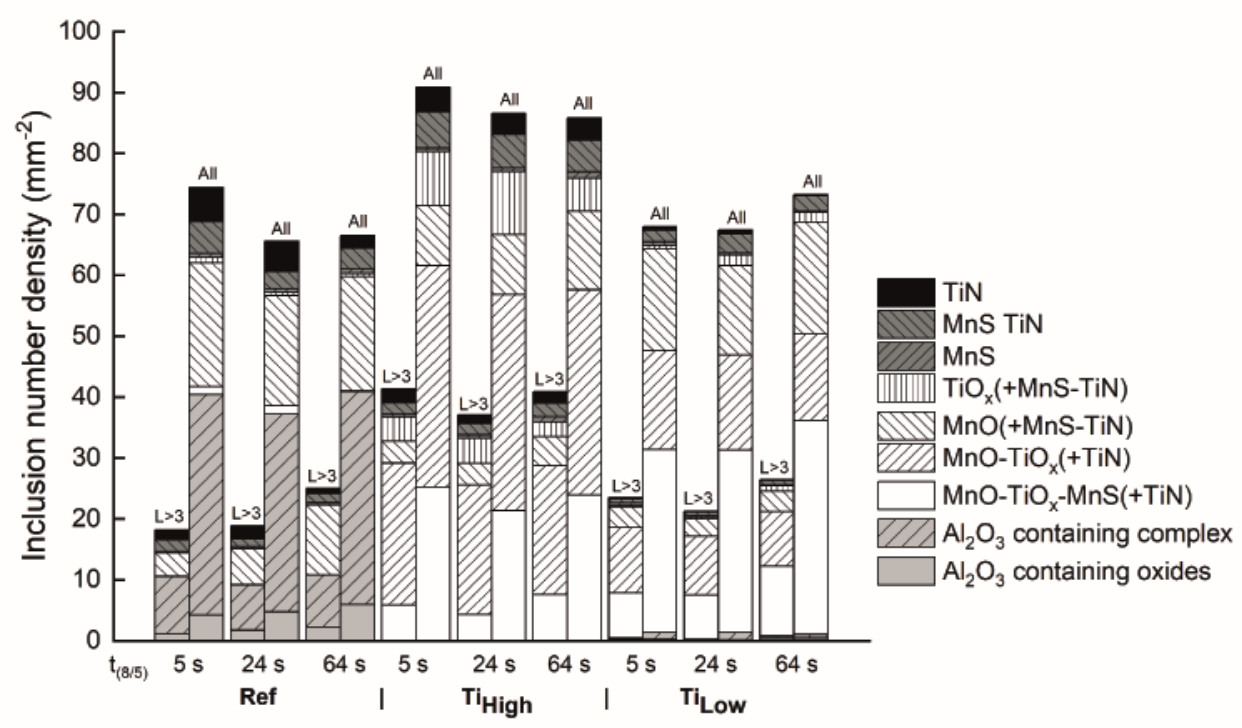

b)

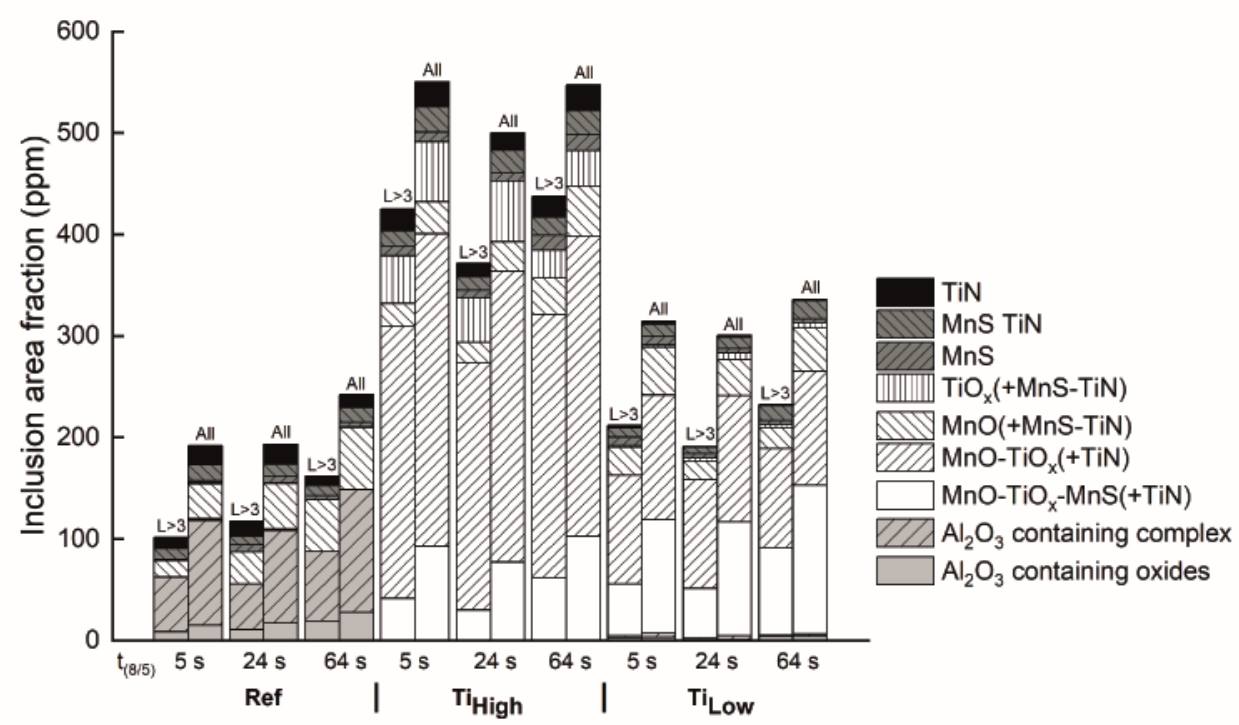

Figure 7. Number density (a) and area fraction (b) of inclusions coarser than $3 \mu \mathrm{m}$ and all inclusions in the studied steels.

\subsection{Precipitates}

Nanoscale precipitates existing in the studied steels were studied by using carbon extraction replicas and TEM. In all the variants, TiN precipitates were found to also contain other elements, such as $\mathrm{C}, \mathrm{Nb}, \mathrm{V}, \mathrm{Fe}$ and/or Mn. Additionally, cementite $\left(\mathrm{Fe}_{3} \mathrm{C}\right)$ was commonly found. Figure 8 presents a typical TiN precipitate. Interestingly, in $\mathrm{Ti}_{\mathrm{low}}$ with $t_{8 / 5}=5 \mathrm{~s}, \mathrm{TiN}-\mathrm{Al}_{2} \mathrm{O}_{3}$ and $\mathrm{MnO}-\mathrm{Al}_{2} \mathrm{O}_{3}-\mathrm{TiN}$ precipitates were also found, which were not present in the other studied samples.

The numerical data of the precipitates in the studied steels are summarized in Table 6. The highest number of precipitates was found in $\mathrm{Ti}_{\text {high }}$, where the highest number of microscale inclusions was also found (Figure 7). The lowest number of precipitates was found in $\mathrm{Ti}_{\text {low }}$ with $t_{8 / 5}=5 \mathrm{~s}$, which may explain the coarsened prior austenite grain size in the CGHAZ of $\mathrm{Ti}_{\text {low }}$. On the other hand, in $\mathrm{Ti}_{\text {low }}$ with $t_{8 / 5}=64 \mathrm{~s}$, there were more precipitates than in Ref and close to that of $\mathrm{Ti}_{\text {high }}$, which does not support making conclusions about 
the role of precipitates on PAGS. Obviously, the relatively small investigated area partly explains the inconsistencies.

TiN with traces of $\mathrm{C}, \mathrm{Nb}$ and $\mathrm{V}$

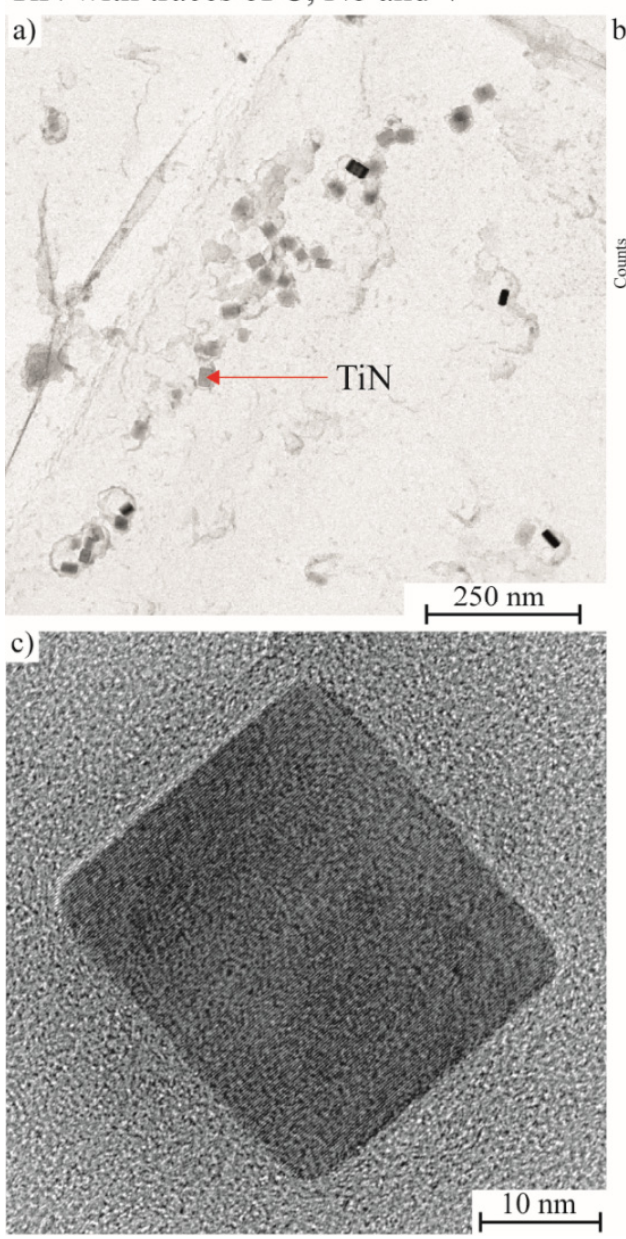

b)

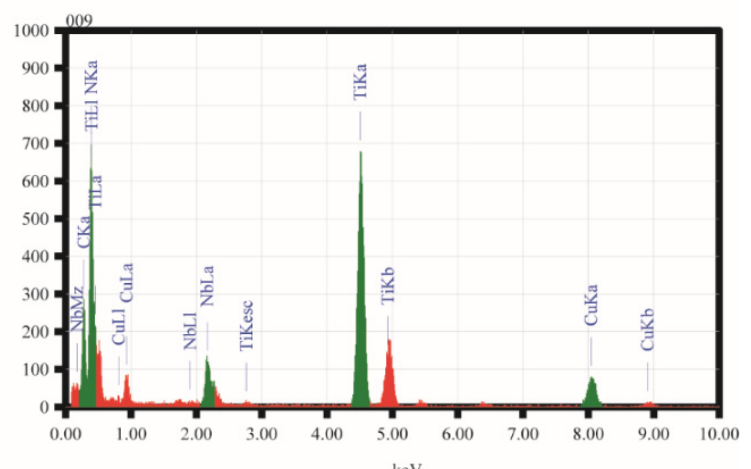

$\mathrm{keV}$

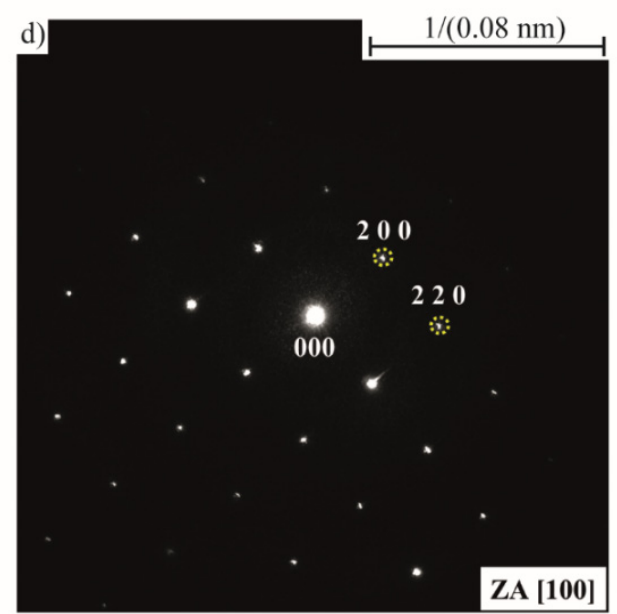

Figure 8. TiN observed in the studied steels (a) with energy-dispersive X-ray spectrometry (EDS) analysis (b). A single TiN precipitate (c) with its lattice structure (d).

Table 6. Precipitation data of the investigated steels. Total investigated area was $(3.16 \mu \mathrm{m} \times 3.16 \mu \mathrm{m}$ $\times 10$ fields) $100 \mu \mathrm{m}^{2}$.

\begin{tabular}{|c|c|c|c|c|c|c|c|c|c|}
\hline Data Type & $\begin{array}{c}\text { Ref } \\
5 \mathrm{~s}\end{array}$ & $\begin{array}{c}\mathrm{Ti}_{\text {high }} \\
5 \mathrm{~s}\end{array}$ & $\begin{array}{c}\mathbf{T i}_{\text {low }} \\
5 \mathrm{~s}\end{array}$ & $\begin{array}{l}\text { Ref } \\
24 \mathrm{~s}\end{array}$ & $\begin{array}{c}\mathrm{Ti}_{\text {high }} \\
24 \mathrm{~s}\end{array}$ & $\begin{array}{c}\mathrm{Ti}_{\text {low }} \\
24 \mathrm{~s}\end{array}$ & $\begin{array}{l}\text { Ref } \\
64 \mathrm{~s}\end{array}$ & $\begin{array}{c}\mathrm{Ti}_{\text {high }} \\
64 \mathrm{~s}\end{array}$ & $\begin{array}{c}\mathrm{Ti}_{\text {low }} \\
64 \mathrm{~s}\end{array}$ \\
\hline No. of precipitates & 305 & 709 & 230 & 375 & 340 & 299 & 470 & 603 & 551 \\
\hline Average ECD (nm) & 31 & 38 & 35 & 29 & 39 & 39 & 32 & 36 & 32 \\
\hline Confidence Level (95\%) & 2 & 1 & 3 & 1 & 2 & 3 & 2 & 1 & 1 \\
\hline $\mathrm{D} 90 \%(\mathrm{~nm})$ & 62 & 94 & 113 & 50 & 80 & 101 & 94 & 80 & 62 \\
\hline Min. ECD (nm) & 16 & 18 & 20 & 20 & 20 & 17 & 10 & 19 & 16 \\
\hline Max. ECD (nm) & 143 & 160 & 147 & 226 & 138 & 208 & 138 & 189 & 178 \\
\hline
\end{tabular}

\subsection{Fractography}

The fracture surfaces of the CVN specimens were studied by SEM in order to analyze crack initiation and propagation, as well as overall appearance. Fracture surface morphology and brittle fracture initiators of all materials with $t_{8 / 5}=5 \mathrm{~s}$ at $-60{ }^{\circ} \mathrm{C}$ are presented in Figure 9. The Ref steel had considerably larger areas of ductile tearing at the root of the notch, which corresponds to the amount of ductile propagation on load-displacement graphs. The main fracture mode was cleavage fracture on all steels with varying amounts of ductile regions. The cleavage facets seemed to be larger in $\mathrm{Ti}_{\text {low }}$ specimens compared 
with the other steels, which is likely connected to the larger PAGS. At $-80{ }^{\circ} \mathrm{C}$, the fracture mode was completely brittle at both 5 and 64 s cooling times, the latter having some ductile tearing in the root of the notch in Ref specimens. The fracture surfaces of the $24 \mathrm{~s}$ specimens at $-40^{\circ} \mathrm{C}$ were not investigated, since the main focus of this study was in the ductile-brittle transition zone.
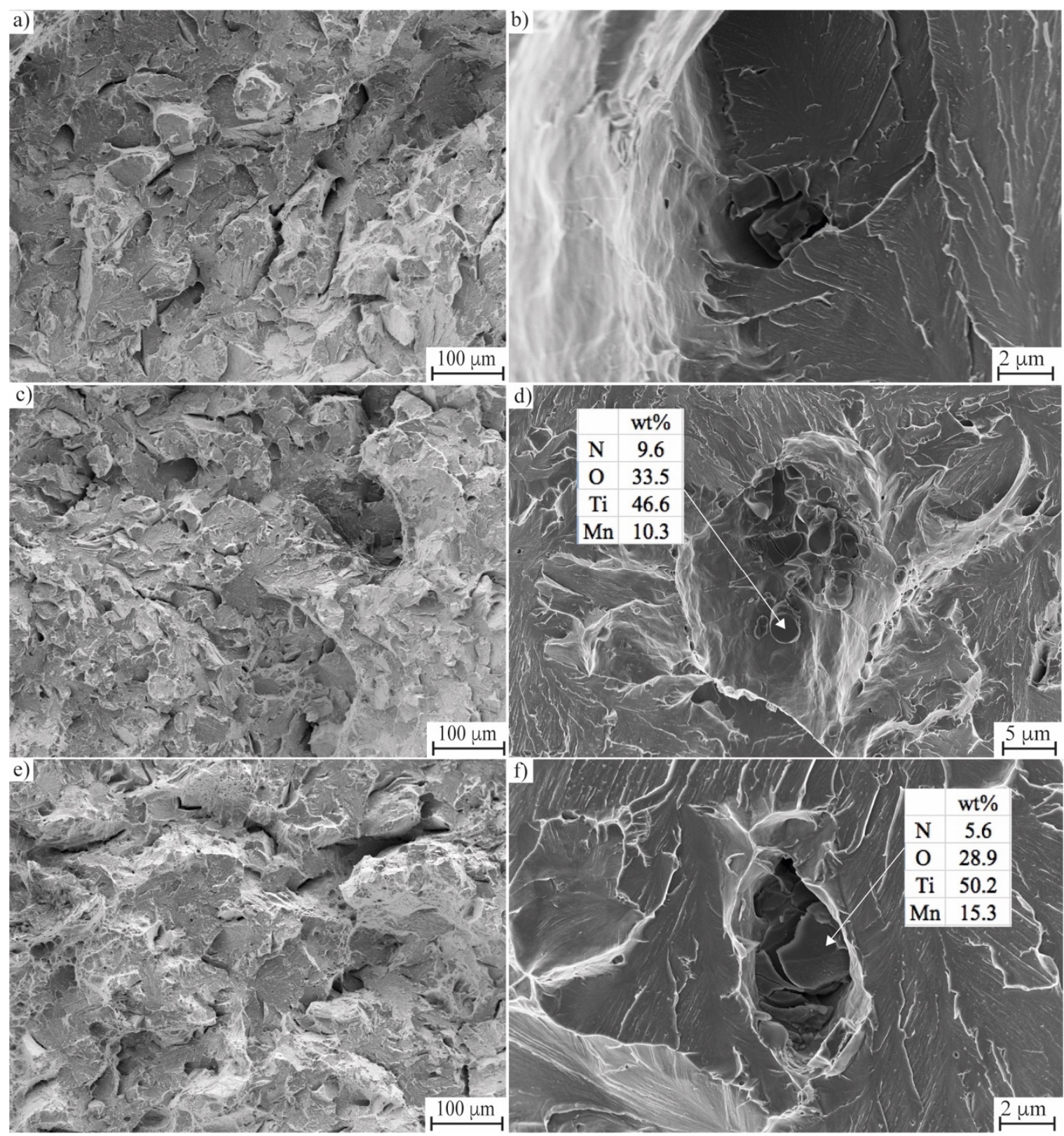

Figure 9. General fractography image from approximately the middle of the fractured surface $(\mathbf{a}, \mathbf{c}, \mathbf{e})$ and a closer look at the inclusions that had initiated the fracture $(\mathbf{b}, \mathbf{d}, \mathbf{f})$ in $\operatorname{Ref}, \mathrm{Ti}_{\text {high }}$ and $\mathrm{Ti}_{\text {low }}$, respectively. Chemical composition of the inclusions $(\mathbf{d}, \mathbf{f})$ measured using EDS. The inclusions in (b) are likely TiN based on their shape, but due to their position in a pit, no reliable compositional measurement could have been conducted.

The fracture surface morphology of the low impact energy (13 J) Ref specimen with $t_{8 / 5}=5 \mathrm{~s}$ is presented in Figure 9a. Fracture morphology shows a relatively small cleavage facet size comparable to that of the $\mathrm{Ti}_{\text {high }}$ specimens. However, the fracture pattern shows no dimples, unlike in the $\mathrm{Ti}_{\text {high }}$ and $\mathrm{Ti}_{\text {low }}$ specimens displayed in Figure $9 \mathrm{c}, \mathrm{e}$, respectively. The cleavage facet size of the $\mathrm{Ti}_{\text {low }}$ specimen was considerably larger than that of the other steels. Nevertheless, the absorbed energy of the $\mathrm{Ti}_{\text {low }}$ specimen (36 J) was similar to the 
$\mathrm{Ti}_{\text {high }}$ specimen (33 J). The fracture surface of the $\mathrm{Ti}_{\text {low }}$ specimen revealed more ductile tearing, which may explain the similar results despite having a larger cleavage facet size. However, the $t_{8 / 5}=64 \mathrm{~s}$ specimens of $\mathrm{Ti}_{\text {low }}$ lacked the ability to impede crack propagation, as evidenced by the lower $E_{i}$ and $E_{p}$ in Table 3.

Fractographic analysis showed that the brittle fracture was initiated by coarse inclusions or clusters of inclusions. In the case of the Ref material, fracture initiators were coarse TiN inclusions, as shown in Figure 9b. On Ti-deoxidized specimens, the brittle fracture initiations were located at $\mathrm{TiO}_{x}$ and $\mathrm{MnO}^{-} \mathrm{TiO}_{\mathrm{x}}$ inclusions or inclusion clusters containing $\mathrm{TiO}_{x}$ particles and other Ca-based inclusions. However, the failure initiators were not found in all of the investigated specimens.

Overall, the impact toughness of the Ref steel was slightly better than that of the Ti-deoxidized steels. The fracture surfaces at $-60^{\circ} \mathrm{C}$ showed similar features between all materials for the most part. However, the $\mathrm{Ti}_{\text {low }}$ specimens with $t_{8 / 5}=64 \mathrm{~s}$ demonstrated highly brittle behavior compared with the other steels. The PAGS of $\mathrm{Ti}_{\text {low }}$ was larger than on the other steels and was observed at a larger cleavage fracture facet size. However, the deteriorated impact toughness could not be completely attributed to the larger PAGS since higher energies were observed with other cooling rates that had similar coarse fracture morphology. Instead, impact toughness seemed to correlate with the amount of ductile areas in the fracture surface. Interestingly, even the highest amount of $\mathrm{AF}(46 \%)$ produced by this cooling rate seemed to be inadequate in effectively hindering crack propagation. The work from Xiong et al. showed that the AF in Ti-deoxidized steels can be effective in improving the impact toughness of CGHAZ by increasing the number of high angle boundaries [22]. The fraction of the AF was not determined in the aforementioned study, but the cooling time of $t_{8 / 5}=80 \mathrm{~s}$ was used. Therefore, there are likely differences between the $\mathrm{AF}$ fractions compared to the present study.

Figure 10 shows, as an example, the macroscale fractographies of the variants with the shortest and longest cooling time $\left(t_{8 / 5}=5 \mathrm{~s}\right.$ and $\left.64 \mathrm{~s}\right)$ tested at $-60^{\circ} \mathrm{C}$. It is evident that most deformations can be observed in the Ref samples ( $a$ and d) that showed comparably good impact toughness. Generally, the fractographies of $t_{8 / 5}=64 \mathrm{~s}$ samples $(\mathrm{d}, \mathrm{e}, \mathrm{f})$ appeared coarser compared to those of $t_{8 / 5}=5 \mathrm{~s}$, especially in the case of $\mathrm{Ti}_{\text {low }}$ with $t_{8 / 5}=64 \mathrm{~s}(\mathrm{f})$, where fracture had occurred at nearly $100 \%$ of the area in brittle mode.

\subsection{Regression Modeling}

Multivariate linear regression models were prepared for the CVN and characterized microstructural features as presented in Table 7. The parameters used contained the toughness, inclusion data, phase fractions and grains sizes that were determined. The significance of all the variables was considered, and those that had $p>0.05$ were excluded from the models. The variance inflation factor (VIF) was used to assess the multicollinearity of the independent variables. The presented models had no VIF $>5$ instances. In model $\mathrm{B}$, two outliers $( \pm 3 \mathrm{SD})$ from the residuals were subtracted from the analyses in order to mitigate their influence. Models C, D and E examined the factors contributing to crack initiation, propagation and arrest, respectively.

The models generally show beneficial attributions of plate-like bainite relative to absorbed energy. Large inclusions or retained austenite were generally observed as harmful. Other phases and precipitates had occasional significance, but their effects varied. In particular, the modelling for the instrumented CVN data showed high variance and varying correlation coefficients. 


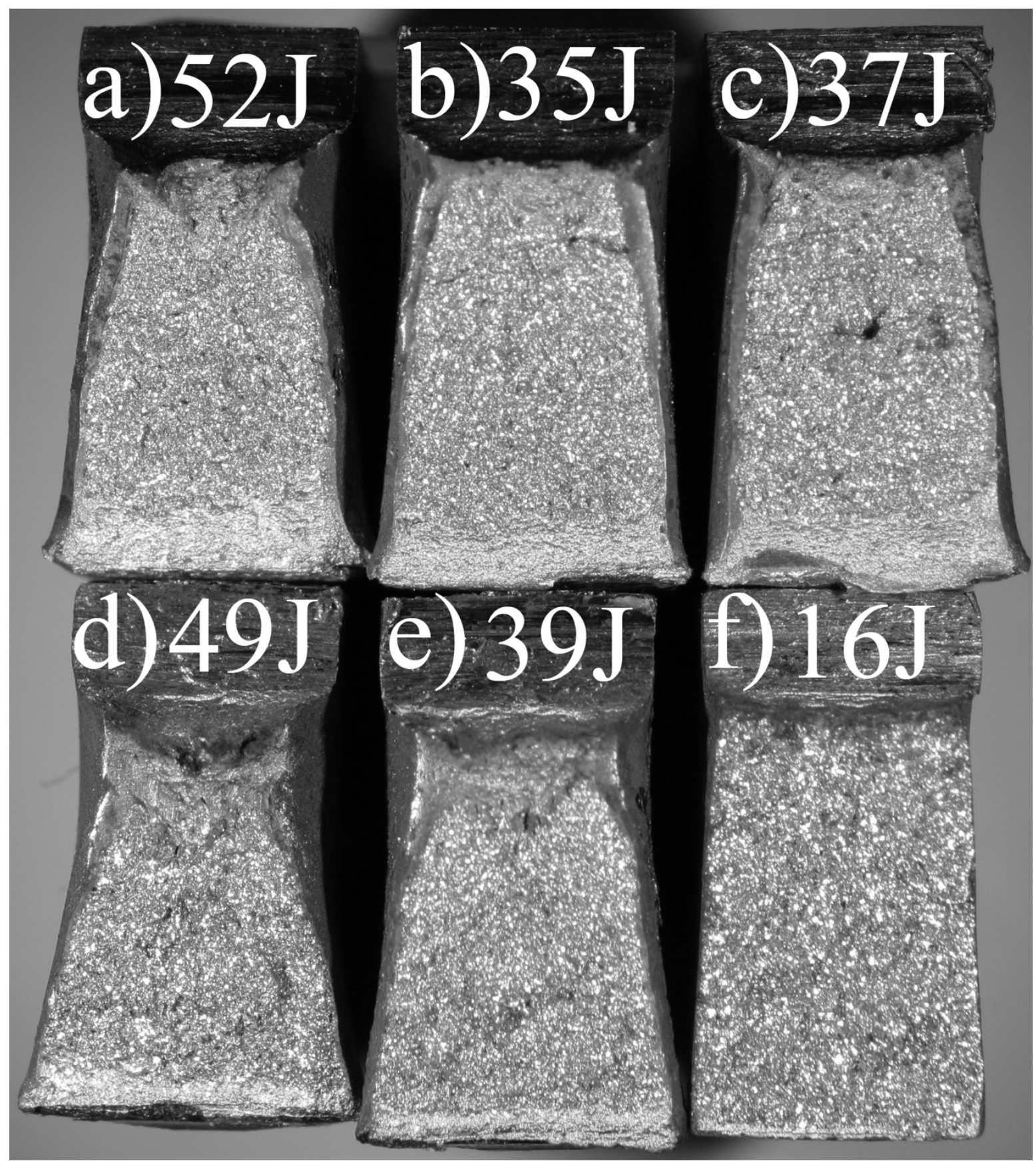

Figure 10. Macroscale fractographies and the corresponding impact toughness energies of Ref, $\mathrm{Ti}_{\text {high }}$ and $\mathrm{Ti}_{\text {low }}$ with $t_{8 / 5}=5 \mathrm{~s}(\mathbf{a}-\mathbf{c})$ and with $t_{8 / 5}=64 \mathrm{~s}(\mathbf{d}-\mathbf{f})$, respectively, tested at $-60{ }^{\circ} \mathrm{C}$. 
Table 7. Regression modeling.

\begin{tabular}{|c|c|c|c|c|c|}
\hline Parameter & Model A & Model B & Model C & Model D & Model E \\
\hline $\mathrm{n}$ & 27 & 52 & 54 & 53 & 54 \\
\hline Constant & 23.9 & $*$ & $* *$ & $* * *$ & $* * * *$ \\
\hline Plate-like bainite & 1.183 & 0.802 & 0.223 & 0.421 & - \\
\hline Lath-like bainite & - & - & - & -0.445 & - \\
\hline Acicular ferrite & - & - & -0.331 & - & - \\
\hline ECD $90 \%$ & - & - & - & - & -0.044 \\
\hline Retained austenite & - & -6.27 & - & -4.20 & -1.198 \\
\hline Inclusions $>3 \mu \mathrm{m} / \mathrm{mm}^{2}$ & -1.343 & -1.130 & - & -0.721 & - \\
\hline $\mathrm{MnS} \mathrm{TiN}>3 \mu \mathrm{m} / \mathrm{mm}^{2}$ & - & - & -9.650 & - & - \\
\hline R-sq(adj) & 0.57 & 0.85 & 0.69 & 0.78 & 0.66 \\
\hline SE & 14 & 10 & 6 & 7 & 2 \\
\hline $\begin{array}{r}\text { Model B = C } \\
\text { M }\end{array}$ & $\begin{array}{l}\text { Model A } \\
\text { absorbed er } \\
29.45(-80 \\
\text { el C = CVN } \\
23.61(-80 \\
\mathrm{D}=\mathrm{CVN} \\
21.99(-80 \\
\text { del E = CV } \\
* * 6.54(-8\end{array}$ & $\begin{array}{l}\mathrm{N} \text { absorbec } \\
\text { at }-80 \ldots \\
4.55\left(-60^{\circ}\right. \\
\text { initiation } \\
33.85(-60 \\
\text { propagation } \\
36.02(-60 \\
\text { ck arrest en } \\
7.69\left(-60^{\circ}\right.\end{array}$ & $\begin{array}{l}\text { gy at }-60 \\
C, \text { two out } \\
\text { d } 73.58(-4 \\
y \text { at }-80 \ldots \\
\text { hd } 34.16(- \\
\text { rgy at }-80 \\
\text { nd } 46.10(- \\
\text { at }-80 \ldots \\
\text { d } 12.73(-4\end{array}$ & $\begin{array}{l} \pm 3 \mathrm{SD} \text { ) rem } \\
{ }^{\circ} \mathrm{C} \\
40{ }^{\circ} \mathrm{C} \\
\mathrm{C}\end{array}$ & \\
\hline
\end{tabular}

\section{Conclusions}

Three experimental laboratory steels were studied in order to measure the effect of acicular ferrite on impact toughness. The studied steels were two Ti-deoxidized steels with a varying fraction of acicular ferrite and Al-deoxidized reference steel, with otherwise comparable chemistry. In contrast to other studies, acicular ferrite was not found to improve the impact toughness of CGHAZ in this study, and the best impact toughness was achieved in conventional Al-deoxidized reference steel that did not have any or a remarkable fraction of acicular ferrite. The possible reasons for the weak impact toughness in the acicular ferrite-containing steels were a coarser prior austenite grain size and effective grain size, a marginally higher hardness/tensile strength and unbeneficial coarse inclusions. It is also possible that a higher fraction of acicular ferrite in the microstructure would be needed in order to observe the beneficial effect on impact toughness than was achieved in this study.

Author Contributions: Conceptualization, H.T., A.K. and S.A.; methodology, T.A., V.J. and M.A.; formal analysis, H.T., S.A., T.A., M.M., M.A. and V.J.; investigation, H.T., M.A., M.M. and S.A.; resources, S.A., T.A. and V.J.; data curation, H.T.; writing-original draft preparation, H.T., S.A., V.J., M.M., M.A. and T.A.; writing-review and editing, H.T., A.K., S.A., V.J., M.M., M.A. and T.A.; visualization, H.T., S.A., V.J., M.M., M.A. and T.A.; supervision, A.K. and J.K.; project administration, A.K. and J.K.; funding acquisition, J.K. All authors have read and agreed to the published version of the manuscript.

Funding: The authors are grateful to Business Finland for financing this work as a part of the research project 7537/31/2018 (ISA-Intelligent Steel Applications).

Institutional Review Board Statement: Not applicable.

Informed Consent Statement: Not applicable.

Data Availability Statement: Not applicable.

Acknowledgments: SSAB Europe is acknowledged for the provision of the studied materials. Ilpo Alasaarela, Juha Uusitalo and Tun Tun Nyo are acknowledged for sample preparation and Gleeble simulation.

Conflicts of Interest: The authors declare no conflict of interest. 


\section{References}

1. Willms, R. High strength steel for steel constructions. In Proceedings of the Nordic Steel Construction Conference, Malmö, Sweden, 2-4 September 2009; pp. 597-604.

2. SFS SFS-EN 10225: Weldable Structural Steels for Fixed Offshore Structures. Technical Delivery Conditions. 2009. Available online: https:/ / sales.sfs.fi/fi/index/tuotteet/SFS/CEN/ID2/1/772841.html.stx (accessed on 7 October 2021).

3. Lan, L.; Qiu, C.; Zhao, D.; Gao, X.; Du, L. Microstructural characteristics and toughness of the simulated coarse grained heat affected zone of high strength low carbon bainitic steel. Mater. Sci. Eng. A 2011, 529, 192-200. [CrossRef]

4. Di Schino, A. Analysis of heat treatment effect on microstructural features evolution in a micro-alloyed martensitic steel. Acta Met. Slovaca 2016, 22, 266. [CrossRef]

5. Loder, D.; Michelic, S.K.; Bernhard, C. Acicular ferrite formation and its influencing factors-A review. J. Mater. Sci. Res. 2017, 6, 24-43. [CrossRef]

6. Sarma, D.S.; Karasev, A.V.; Jönsson, P.G. On the role of non-metallic inclusions in the nucleation of acicular ferrite in steels. ISIJ Int. 2009, 49, 1063-1074. [CrossRef]

7. Zhang, D.; Terasaki, H.; Komizo, Y. In situ observation of the formation of intragranular acicular ferrite at non-metallic inclusions in C-Mn steel. Acta Mater. 2010, 58, 1369-1378. [CrossRef]

8. Homma, H.; Ohkita, S.; Matsuda, S.; Yamamoto, K. Improvement of HAZ in HSLA steel by introducing finely dispersed Ti-Oxide. Weld. Res. Suppl. 1987, 66, 301-309.

9. Laitinen, R. Improvement of Weld HAZ Toughness at Low Heat Input by Controlling the Distribution of M-A Constituents; University of Oulu: Oulu, Finland, 2006.

10. Haaland, D.; Van Der Eijk, C.; Grong, Ø. The role of interactive particles in steel. In Proceedings of the International Symposium "Safety in Application of High Strength Steel", Trondheim, Norway, 1-2 July 1997.

11. Kim, B.; Uhm, S.; Lee, C.; Lee, J.; An, Y. Effects of inclusions and microstructures on impact energy of high heat-input submergedArc-weld metals. J. Eng. Mater. Technol. 2005, 127, 204-213. [CrossRef]

12. Thewlis, G. Transformation kinetics of ferrous weld metals. Mater. Sci. Technol. 1994, 10, 110-125. [CrossRef]

13. Barbaro, F.J.; Krauklis, P.; Easterling, K.E. Formation of acicular ferrite at oxide particles in steels. Mater. Sci. Technol. 1989, 5, 1057-1068. [CrossRef]

14. Shim, J.-H.; Cho, Y.; Chung, S.; Shim, J.-D.; Lee, D. Nucleation of intragranular ferrite at Ti2O3 particle in low carbon steel. Acta Mater. 1999, 47, 2751-2760. [CrossRef]

15. Byun, J.-S.; Shim, J.-H.; Suh, J.-Y.; Oh, Y.-J.; Cho, Y.W.; Shim, J.-D.; Lee, D.N. Inoculated acicular ferrite microstructure and mechanical properties. Mater. Sci. Eng. A 2001, 319-321, 326-331. [CrossRef]

16. Yamamoto, K.; Matsuda, S.; Haze, T.; Chijiiwa, R.; Mimura, H. A newly developed Ti-Oxide bearing steel having high HAZ toughness. In Residual and Unspecified Elements in Steel; Melilli, A.S., Nisbett, E.G., Eds.; ASTM International: West Conshohocken, PA, USA, 1989; pp. 266-284. ISBN 978-0-8031-5097-3.

17. Fukunaga, K.; Yoshii, K.; Shinohara, Y.; Yoneda, T.; Watanabe, Y.; Usuki, H.; Iki, H. High Strength TMCP Steel Plate for Offshore Structure with Excellent HAZ Toughness at Welded Joints. 2015. Available online: https:/ /www.nipponsteel.com/en/tech/ report/nssmc/pdf/110-08.pdf (accessed on 4 November 2021).

18. Tomita, Y.; Saito, N.; Tsuzuki, T.; Tokunaga, Y.; Okamoto, K. Improvement in HAZ toughness of steel by TiN-MnS addition. ISIJ Int. 1994, 34, 829-835. [CrossRef]

19. Wang, X.; Wang, C.; Kang, J.; Wang, G.; Misra, D.; Yuan, G. Relationship between impact toughness and microstructure for the As-Rolled and simulated HAZ of low-carbon steel containing Ti-Ca oxide particles. Met. Mater. Trans. A 2020, 51, 2927-2938. [CrossRef]

20. Lee, S.G.; Lee, D.H.; Sohn, S.S.; Kim, W.G.; Um, K.-K.; Kim, K.-S.; Lee, S. Effects of Ni and Mn addition on critical crack tip opening displacement (CTOD) of weld-simulated heat-affected zones of three high-strength low-alloy (HSLA) steels. Mater. Sci. Eng. A 2017, 697, 55-65. [CrossRef]

21. Huang, G.; Wan, X.L.; Wu, K.M. Effect of Cr content on microstructure and impact toughness in the simulated coarse-grained heat-affected zone of high-strength low-alloy steels. Steel Res. Int. 2016, 87, 1426-1434. [CrossRef]

22. Xiong, Z.; Liu, S.; Wang, X.; Shang, C.; Li, X.; Misra, R.D.K. The contribution of intragranular acicular ferrite microstructural constituent on impact toughness and impeding crack initiation and propagation in the heat-affected zone (HAZ) of low-carbon steels. Mater. Sci. Eng. A 2015, 636, 117-123. [CrossRef]

23. Grong, Ø. Metallurgical Modelling of Welding; Bhadeshia, H.K.D.H., Ed.; Materials; The Institute of Materials: Cambridge, UK, 1994.

24. Tervo, H.; Kaijalainen, A.; Pallaspuro, S.; Anttila, S.; Mehtonen, S.; Porter, D.; Kömi, J. Low-temperature toughness properties of $500 \mathrm{MPa}$ offshore steels and their simulated coarse-grained heat-affected zones. Mater. Sci. Eng. A 2020, 773, 138719. [CrossRef]

25. Spachinger, S.J.; Ernst, W.; Enzinger, N. Influence of Ti on the toughness of the FGHAZ and the CGHAZ of high-strength microalloyed S700MC steels. Weld. World 2017, 61, 1117-1131. [CrossRef]

26. Zhang, L.P.; Davis, C.L.; Strangwood, M. Effect of TiN particles and microstructure on fracture toughness in simulated heataffected zones of a structural steel. Met. Mater. Trans. A 1999, 30, 2089-2096. [CrossRef]

27. Liang, G.L.; Yang, S.W.; Wu, H.B.; Liu, X.L. Microstructure and mechanical performances of CGHAZ for oil tank steel during high heat input welding. Rare Met. 2013, 32, 129-133. [CrossRef] 
28. Wang, X.-N.; Chen, X.-M.; Wen, F.; Guo, P.-F.; Yang, L.; Yan, Q.; Di, H.-S. Effect of cooling time t 8/5 on microstructure and toughness of $\mathrm{Nb}-\mathrm{Ti}-\mathrm{Mo}$ microalloyed C-Mn steel. J. Iron Steel Res. Int. 2018, 25, 1078-1085. [CrossRef]

29. Ding, Q.; Wang, T.; Shi, Z.; Wang, Q.; Wang, Q.; Zhang, F. Effect of welding heat input on the microstructure and toughness in simulated CGHAZ of $800 \mathrm{MPa}$-grade steel for hydropower penstocks. Metals 2017, 7, 115. [CrossRef]

30. Shi, Z.; Wang, R.; Su, H.; Chai, F.; Wang, Q.; Yang, C. Effect of nitrogen content on the second phase particles in V-Ti microalloyed shipbuilding steel during weld thermal cycling. Mater. Des. 2016, 96, 241-250. [CrossRef]

31. Kumar, S.; Nath, S.K. Effect of heat input on impact toughness in transition temperature region of weld CGHAZ of a HY 85 steel. J. Mater. Process. Technol. 2016, 236, 216-224. [CrossRef]

32. Kumar, S.; Nath, S.K.; Kumar, V. Continuous cooling transformation behavior in the weld coarse grained heat affected zone and mechanical properties of Nb-microalloyed and HY85 steels. Mater. Des. 2016, 90, 177-184. [CrossRef]

33. Zhou, Y.; Jia, T.; Zhang, X.; Liu, Z.; Misra, R.D.K. Microstructure and toughness of the CGHAZ of an offshore platform steel. J. Mater. Process. Technol. 2015, 219, 314-320. [CrossRef]

34. Lan, L.; Qiu, C.; Zhao, D.; Gao, X.; Du, L. Analysis of martensite-austenite constituent and its effect on toughness in submerged arc welded joint of low carbon bainitic steel. J. Mater. Sci. 2012, 47, 4732-4742. [CrossRef]

35. Lambert-Perlade, A.; Gourgues, A.F.; Besson, J.; Sturel, T.; Pineau, A. Mechanisms and modeling of cleavage fracture in simulated heat-affected zone microstructures of a high-strength low alloy steel. Met. Mater. Trans. A Phys. Met. Mater. Sci. 2004, 35, 1039-1053. [CrossRef]

36. Lan, L.; Kong, X.; Qiu, C.; Zhao, D. Influence of microstructural aspects on impact toughness of multi-pass submerged arc welded HSLA steel joints. Mater. Des. 2016, 90, 488-498. [CrossRef]

37. Tervo, H.; Kaijalainen, A.; Javaheri, V.; Kolli, S.; Alatarvas, T.; Anttila, S.; Kömi, J. Characterization of coarse-grained heat-affected zones in $\mathrm{Al}$ and Ti-deoxidized offshore steels. Metals 2020, 10, 1096. [CrossRef]

38. Gáspár, M. Effect of welding heat input on simulated HAZ areas in S960QL high strength steel. Metals 2019, 9, 1226. [CrossRef]

39. Luo, X.; Chen, X.; Wang, T.; Pan, S.; Wang, Z. Effect of morphologies of martensite-austenite constituents on impact toughness in intercritically reheated coarse-grained heat-affected zone of HSLA steel. Mater. Sci. Eng. A 2018, 710, 192-199. [CrossRef]

40. ISO 14556: 2015: Metallic Materials. Charpy V-Notch Pendulum Impact Test. Instrumented Test Method. Available online: https: / / www.iso.org/standard/63814.html (accessed on 4 November 2021).

41. Javaheri, V.; Pohjonen, A.; Asperheim, J.I.; Ivanov, D.; Porter, D. Physically based modeling, characterization and design of an induction hardening process for a new slurry pipeline steel. Mater. Des. 2019, 182, 108047. [CrossRef]

42. DeArdo, A.J.; Garcia, C.I.; Cho, K.; Hua, M. New method of characterizing and quantifying complex microstructures in steels. Mater. Manuf. Process. 2010, 25, 33-40. [CrossRef]

43. Nyyssönen, T.; Isakov, M.; Peura, P.; Kuokkala, V.-T. Iterative determination of the orientation relationship between austenite and martensite from a large amount of grain pair misorientations. Met. Mater. Trans. A 2016, 47, 2587-2590. [CrossRef]

44. Nyyssönen, T.; Peura, P.; Kuokkala, V.-T. Crystallography, morphology, and martensite transformation of prior austenite in intercritically annealed high-aluminum steel. Met. Mater. Trans. A 2018, 49, 6426-6441. [CrossRef]

45. Javaheri, V.; Nyyssönen, T.; Grande, B.; Porter, D. Computational design of a novel medium-carbon, low-alloy steel microalloyed with niobium. J. Mater. Eng. Perform. 2018, 27, 2978-2992. [CrossRef]

46. Javaheri, V.; Kolli, S.; Grande, B.; Porter, D. Insight into the induction hardening behavior of a new $0.40 \%$ C microalloyed steel: Effects of initial microstructure and thermal cycles. Mater. Charact. 2019, 149, 165-183. [CrossRef]

47. Kurdjumow, G.; Sachs, G. Uber den mechanismus der stahlhärtung. Zeitschrift für Physik 1930, 64, 325-343. [CrossRef]

48. Ali, M.; Porter, D.; Kömi, J.; Eissa, M.; El Faramawy, H.; Mattar, T. Characterization of the microstructure and precipitates formed during the thermomechanical processing of a CrNiMoWMnV ultrahigh-strength steel. Steel Res. Int. 2020, 91, 1900580. [CrossRef]

49. Ali, M.; Porter, D.; Kömi, J.; Eissa, M.; El Faramawy, H.; Mattar, T. The effect of electroslag remelting on the microstructure and mechanical properties of CrNiMoWMnV ultrahigh-strength steels. Metals 2020, 10, 262. [CrossRef]

50. Zajac, S.; Komenda, J.; Morris, P.; Matera, S.; Penalba Diaz, F. Quantitative Structure-Property Relationships for Complex. Bainitic Microstructure. RFCS Final Report; European Commission: Luxembourg, 2005. 